\title{
The Roles of Corporate Governance in Bank Failures During the Recent Financial Crisis
}

\author{
Berger, Allen N.; Imbierowicz, Björn; Rauch, Christian
}

\author{
Document Version \\ Accepted author manuscript \\ Published in: \\ Journal of Money, Credit and Banking \\ DOI: \\ 10.1111/jmcb.12316 \\ Publication date: \\ 2016 \\ License \\ Unspecified
}

Citation for published version (APA):

Berger, A. N., Imbierowicz, B., \& Rauch, C. (2016). The Roles of Corporate Governance in Bank Failures During the Recent Financial Crisis. Journal of Money, Credit and Banking, 48(4), 729-770.

https://doi.org/10.1111/jmcb.12316

Link to publication in CBS Research Portal

\section{General rights}

Copyright and moral rights for the publications made accessible in the public portal are retained by the authors and/or other copyright owners and it is a condition of accessing publications that users recognise and abide by the legal requirements associated with these rights.

\section{Take down policy}

If you believe that this document breaches copyright please contact us (research.lib@cbs.dk) providing details, and we will remove access to the work immediately and investigate your claim.

Download date: 26. Apr. 2023
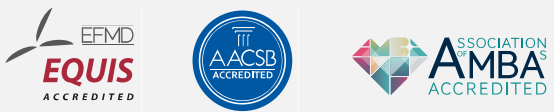


\section{The Roles of Corporate Governance in Bank Failures during the Recent Financial Crisis}

\section{Allen N. Berger, Björn Imbierowicz and Christian Rauch}

Journal article (Post print version)

This is the peer reviewed version of the following article: The Roles of Corporate Governance in Bank Failures during the Recent Financial Crisis. / Berger, Allen N.; Imbierowicz, Björn; Rauch, Christian. In: Journa/ of Money, Credit \& Banking, Vol. 48, No. 4, 2016, p. 729-770., which has been published in final form at http://dx.doi.org/10.11ll/jmcb.12316. This article may be used for non-commercial purposes in accordance with Wiley Terms and Conditions for Self-Archiving.

Uploaded to Research@CBS: July 2016 


\title{
The Roles of Corporate Governance in Bank Failures During the Recent Financial Crisis
}

\author{
Berger, Allen N. \\ H. Montague Osteen, Jr., Professor in Banking and Finance and Carolina Distinguished Professor \\ Moore School of Business, University of South Carolina \\ Email: aberger@moore.sc.edu \\ Imbierowicz, Björn \\ Assistant Professor \\ Copenhagen Business School and Center for Financial Frictions (FRIC) \\ Email: bi.fi@cbs.dk \\ Rauch, Christian \\ Barclays Fellow in Entrepreneurial Finance \\ Saïd Business School, University of Oxford \\ Email: christian.rauch@sbs.ox.ac.uk
}

JEL Codes: G21, G28, G32, G34

Keywords: Bank Default, Corporate Governance, Bank Regulation

\begin{abstract}
The authors thank the editor, Bob DeYoung, and two anonymous referees, as well as Lamont Black, Barbara Casu, Zhongdong Chen, Rebel Cole, Meg Donovan, Isil Erel, Michael Erkens, Rüdiger Fahlenbrach, Karolin Kirschenmann, Tomislav Ladika, Xiaoding Liu, Daniel Metzger, Lars Norden, Raluca Roman, Klaus Schaeck, Ken Spong, Laura Starks, Sascha Steffen, Nuria Suárez, Rick Sullivan, Larry D. Wall, and participants at the Bank Workshop in Münster, the GdRE International Symposium on Money, Banking and Finance, the Southern Finance Association Annual Meeting, the Financial Management Association Annual Meeting, the European Finance Association Annual Meeting, the Emerging Scholars Conference, the Financial Stability Conference of the European Banking Center at Tilburg University, the ASSA Annual Meeting, the Campus for Finance Meeting, as well as seminar participants at the Erasmus University Rotterdam, Tilburg University, and the University of Kansas for useful comments.
\end{abstract}




\begin{abstract}
We analyze the roles of bank ownership, management, and compensation structures in bank failures during the recent financial crisis. Our results suggest that failures are strongly influenced by ownership structure: high shareholdings of lower-level management and non-CEO higherlevel management increase failure risk significantly. In contrast, shareholdings of banks' CEOs do not have a direct impact on bank failure. These findings suggest that high stakes in the bank induce non-CEO managers to take high risks due to moral hazard incentives, which may result in bank failure. We identify tail risk in non-interest income as a primary risk-taking channel of lower-level managers.
\end{abstract}


"In the wake of the crisis, financial institution (FI) governance was too often revealed as a set of arrangements that approved risky strategies (which often produced unprecedented short-term profits and remuneration), was blind to the looming dangers on the balance sheet and in the global economy, and therefore failed to safeguard the FI, its customers and shareholders, and society at large.” (Group of Thirty (G30) 2012, p. 5)

Why do banks fail? After every crisis, this question is asked by regulators, politicians, bank managers, customers, investors, and academics, hoping that an answer can help improve the stability of the financial system and/or prevent future crises. Although a broad body of research has been able to provide a number of answers to this question, many aspects remain unresolved. The recent financial crisis suggests that the knowledge gained about bank failures is apparently still not sufficient to prevent large numbers of banks from failing.

Most studies of bank failure have focused on the influence of accounting variables, such as capital ratios, non-performing loan (NPL) ratios, and earnings (e.g., Martin, 1977; Pettway and Sinkey, 1980; Lane, Looney, and Wansley, 1986; Espahbodi, 1991; Cole and Gunther, 1995, 1998; Helwege, 1996; Schaeck, 2008; Cole and White, 2012). However, almost no research to date has empirically analyzed the influence of corporate governance characteristics, such as ownership structure or management structure, on a bank's probability of failure. ${ }^{1}$ This is perhaps surprising for two reasons. First, as the quote of the G30 Report on Corporate Governance above suggests, ineffective bank corporate governance mechanisms are thought to have played pivotal roles during the recent financial crisis in promoting risk-taking. The G30's perception was echoed by other critics who called for corporate governance-based mechanisms to control bank risk taking during and after the recent financial crisis. Some examples are the restrictions on 
compensation and perks under the Troubled Asset Relief Program (TARP), disclosure of compensation and advisory votes of shareholders about executive compensation under DoddFrank, guidance for compensation such as deferred compensation, alignment of compensation with performance and risk, disclosure of compensation, etc. by the $\mathrm{G} 20$, and discussions in the UK regarding a lifetime ban from the financial services industry on directors of collapsed banks. Second, a body of literature shows that governance mechanisms can have a very strong influence on bank risk taking (e.g., Saunders, Strock, and Travlos, 1990; Gorton and Rosen, 1995; Anderson and Fraser, 2000; Caprio, Laeven, and Levine, 2007; Laeven and Levine, 2009; Pathan, 2009, DeYoung, Peng and Yan, 2013). Despite these calls for changes in corporate governance and the extant literature on its effects on risk taking, there is little existing evidence that corporate governance arrangements lead to actual bank failure. The goal of this paper is to fill this gap in the literature.

We analyze a sample of 85 failed and 256 non-failed US commercial banks during the period 2007:Q1 to 2010:Q3. We use five sets of explanatory variables in multivariate logit regression models of failure. At the core of our analysis are sets of bank share and option ownership, compensation, and management structure proxy variables. To measure these variables, we split all corporate insiders into four distinct groups: outside directors, Chief Executive Officers (CEOs), non-CEO higher-level managers, and lower-level managers. Ownership, compensation and management position is analyzed separately for each group. We define outside directors as all members of the board of directors who do not hold any other position within the respective bank than their board membership. The group of non-CEO higher-level managers is comprised of all chief officers who are not the CEO, such as the Chief Financial Officer (CFO), Chief Lending Officer (CLO), or Chief Risk Officer (CRO). Lower-level managers are other managers of a bank, such as Vice Presidents, Treasurers or unit/department heads. For these groups, we measure 
share- and option holdings (and -awards) as well as salary, long-term incentives and bonus payments. For ownership, we additionally examine whether the bank received funds from TARP, whether the bank or its holding company has public securities, and whether the bank is in a multibank holding company. For management structure, we use the numbers of outside directors, chief officers, and lower-level managers (all normalized by board size), the board size itself, and if the Chairman is also the CEO.

Additional variables are included to control for failure reasons other than governance. We incorporate the impact of accounting variables which are well represented in the established literature on bank failures. We also include measures of market competition, as well as the subprime loan exposure of banks in the bank's market, which could help the bank by weakening or eliminating some of its competition. In addition, we employ economic variables at the state level - GDP growth and the house price inflation - the latter of which is believed to have contributed to instability because banks were only able to partially recover collateral in defaulted mortgage loans when house price inflation was substantially negative. Finally, we account for potential differences across federal bank regulators.

Our results confirm the extant bank failure literature by finding that accounting variables such as the capital ratio, the return on assets, and the proportion of loans that are non-performing help predict bank failure. Our key new finding is that the ownership structure of a bank is also an important predictor of bank failure. Specifically, we find that larger shareholdings of lower-level management and non-CEO higher-level management significantly increase banks' probability of failure. Interestingly, the shareholdings of the CEO appear to have no direct impact on a bank's failure probability. 
These findings are perhaps not surprising for two reasons. First, moral hazard theory based on Merton (1977) suggests that shareholders of banks with deposit insurance have an incentive to take on excessive risks because of their put option. In the event of failure, they have the option to return the assets of the bank to the insurer. Hypothetically, managers with large shareholdings and direct influences on the bank's daily operations may take on more risk because of this moral hazard problem. This problem, however, may not apply as much to CEOs because they have higher public visibility and are more likely to be vilified in the event of failure. This finding is supported by principal-agency models which show that career and reputation concerns play major roles in the decision-making of management (e.g., Holmstrom and Ricart i Costa, 1986; Hirshleifer and Thakor, 1992; Canella, Fraser and Lee, 1995). Second, recent evidence suggests that lower-level management employees are frequently among the most significant risk-takers in banks. One prominent example is the $\$ 6.2$ billion loss incurred by J.P. Morgan Chase in 2012 due to the trades of the "London whale," Bruno M. Iksil. A March 2013 report of a U.S. Senate subcommittee revealed two important features of the case. First, J.P. Morgan Chase's lower-level managers and traders who were involved in the trades obtained higher ownership stakes in the bank through stock-based compensation than their direct C-level superiors. Second, these lowerlevel managers and traders bore the main responsibility for the losses through active risk-seeking and disregard of bank-internal risk controls. ${ }^{2}$

To gain additional insight, we investigate two related questions: first, which types of banks are most prone to being adversely influenced in their failure probability by lower-level management shareholdings? And second, which are the risk-taking channels of lower-level- and non-CEO higher level managers to influence bank failure risk? To answer the first question, we analyze the observed effect of non-CEO- and lower-level shareholdings on failure probability separately for smaller, more closely held banks, and larger banks with broader and more decentralized 
ownership and management structures. We find that the influence of shareholdings of lower-level and non-CEO higher-level managers on failure probability is strongest for larger banks with public securities and in which the Chairman is not the CEO. To answer the second question, we analyze the influence lower-level management shareholdings have on the distributional characteristics of certain risk indicators, such as non-performing loan ratios, Z-Scores, or changes in capital ratios. We find that, among other things, lower-level management shareholdings significantly increase tail risk in non-interest income while non-CEO higher level management shareholdings result in a lower return on assets, more non-performing loans and a lower capital ratio.

The remainder of the paper is structured as follows. In Section I, we provide an overview of the relevant literature regarding corporate governance and bank stability. In Section II, we describe our data set, discuss summary statistics that give anecdotal evidence of the reasons behind bank failures during the recent financial crisis, describe the ownership and management structures of our sample banks, and provide summary statistics on other variables used in our econometric models. Section III discusses our methodology, reports our main multivariate results, and discusses our robustness tests. In Section IV, we test the effects of ownership structure for different kinds of banks and on different risk-taking channels, and Section V concludes.

\section{LITERATURE OVERVIEW}

Our paper builds upon and expands the existing literature in two closely connected areas of research: bank failures and the influence of corporate governance structures on bank risk taking. The literature on bank failures mostly focuses on testing a wide variety of bank accounting 
variables on banks' failure probabilities. Examples that precede the recent financial crisis are Meyer and Pfifer (1970), Martin (1977), Whalen and Thomson (1988), Espahbodi (1991), Thomson (1991, 1992), Cole and Gunther (1995, 1998), Logan (2001), Cole and Fenn (1995) and Kolari et al. (2002). The dominant findings are that the failure probability increases for banks with low capitalization and other measures of poor performance. There are also several papers analyzing the relevant drivers of bank failures during the recent financial crisis: Aubuchon and Wheelock (2010), Cole and White (2012), Berger and Bouwman (2013), DeYoung and Torna (2013), Hong, Huang and $\mathrm{Wu}$ (2014), and $\mathrm{Ng}$ and Roychowdhury (2014). Aubuchon and Wheelock (2010) focus on bank failures in the US, comparing the 2007-2010 period to the 19871992 period. They analyze the influence of local macroeconomic factors on banks' failure probability. Their study shows that banks are highly vulnerable to local economic shocks and that the majority of bank failures occurred in regions which suffered the strongest economic downturns and the highest distress in real estate markets in the US. Ng and Roychowdhury (2014) also analyze bank failures in the US in the crisis period 2007-2010. They show that "addbacks" of loan loss reserves to regulatory capital increase banks' likelihood of failure. Cole and White (2012) perform a test of virtually all accounting-based variables and how these might contribute to bank failure, using logit regression models on US bank failures in 2009. They find that banks with more capital, better asset quality, higher earnings and more liquidity are less likely to fail. Their results also show that bank failure probability is significantly increased by more real estate construction and development loans, commercial mortgages, and multi-family mortgages. Berger and Bouwman (2013) focus on the effects of bank equity capital on survival and market share during both financial crises (including the recent crisis) and normal times. They find that capital helps small banks survive at all times, and is important to large and medium banks as well during banking crises. DeYoung and Torna (2013) focus on the different roles that 
traditional and modern-day banking activities, such as investment banking and private equitytype business, have in the financial distress or failure of banks from 2007 to 2009 in the US. They find that a stronger focus on these modern-day activities significantly increases the failure probability of distressed banks, but has no influence on the failure probability of financially sound banks. Hong, Huang, and Wu (2014) focus on the liquidity risk of banks. Specifically, they analyze the relationship between bank failure and the newly created Basel III liquidity risk metrics, Liquidity Coverage Ratio (LCR) and Net Stable Funding Ratio (NSFR). They find that bank failure probability is negatively correlated with NSFR, but positively correlated with the LCR, but overall these measures only have a limited effect on explaining bank failures. Although our paper is closely related to these studies - especially to the post-crisis research - we significantly expand the scope of the existing analyses to include corporate governance variables and other factors, and are therefore able to substantially contribute to the understanding of bank failure reasons.

Our most important contribution is the addition of detailed ownership and management structure variables to the standard logit regression model of failure. The distress of the banking system in the wake of the recent financial crisis has triggered a discussion about the role of corporate governance structures in the stability of financial institutions. Politicians (e.g., the Financial Crisis Inquiry Commission Report, 2011), think tanks (e.g. the Squam Lake Working Group on Financial Regulation Report, February 2010), Non-Profit Organizations (such as the OECD project report on Corporate Governance and the Financial Crisis, 2009), and academic researchers (an overview of scholarly papers regarding corporate governance and the financial crisis is provided by e.g. Mehran, Morrison, and Shapiro, 2011) have recently acknowledged the importance of corporate governance for bank stability. The discussions resulted in a number of actions from regulators addressing corporate governance in banks, such as restrictions on 
compensation and perks under TARP, various compensation guidelines set forth by the G20, and "clawback" clauses for executive compensation in addition to guidance for deferred compensation in Dodd-Frank. Banks had even started to implement voluntary "clawback" clauses for bonus payments in addition to the mandatory clauses.

However, the finding that corporate governance has implications for bank stability was already established long before the recent financial crisis. Saunders, Strock, and Travlos (1990), Gorton and Rosen (1995), and Anderson and Fraser (2000) show that governance characteristics, such as shareholder composition, have substantial influence on banks' overall stability. Their findings support that bank managers' ownership is among the most important factors in determining bank risk taking. The general finding across these studies is that higher shareholdings of officers and directors induce a higher overall bank risk taking behavior. Saunders, Strock and Travlos (1990) show this for the 1979-1982 period in the US, and Anderson and Fraser (2000) confirm this for the 1987-1989 period. Gorton and Rosen (1995) obtain the same result for the 1984-1990 period, and additionally find that the relationship between managerial shareholdings and bank risk depends on the health of the banking system as a whole: it is strongly pronounced in periods of distress and may be reversed in times of prosperity. Sullivan and Spong (2007) obtain similar results for the period 1991-1994 by showing that more shareholdings of hired managers (which are not the majority owners or founders of a bank) cause higher bank risk. However, they also show that this risk-taking can be mitigated through monitoring by the bank owners, and that owner-managed banks with a higher degree of the owner-managers' wealth concentration in the bank are less risky. Pathan (2009) provides empirical evidence for the period 1997-2004 that US bank holding companies assume higher risks if they have a stronger shareholder representation on the boards. Testing an international sample, Laeven and Levine (2009) show that banks with more diversified and outsider-controlled shareholder bases have overall lower risk than banks 
with highly concentrated shareholder bases in which most of the cash-flow rights pertain to one large (inside or outside) owner. Based on these findings, we have strong reason to believe that corporate governance structures might also have an influence on bank failure probability.

In light of the recent financial crisis, some studies, such as Kirkpatrick (2008), Gropp and Köhler (2010), Beltratti and Stulz (2012), and Erkens, Hung, and Matos (2012) analyze bank ownership structures with special regard to bank risk. ${ }^{3}$ Although there are studies showing that governance structures in banks were not necessarily worse than in non-financial companies in the period leading up to the financial crisis (Adams, 2012), all relevant studies show that governance does have an important influence on bank risk. Testing an international sample of large publicly traded banks, Beltratti and Stulz (2012) find that banks with better governance (in terms of more shareholder-friendly board structures) performed significantly worse during the crisis than other banks and had higher overall stability risk than before the escalation of the crisis. Specifically, they find that banks with higher controlling shareholder ownership are riskier. Gropp and Köhler (2010) largely confirm these results by showing that owner-controlled banks took on greater risks and experienced larger losses during the financial crisis as compared to manager-controlled banks. Their results suggest that a better alignment of shareholders' and managers' interest leads to an increase of risk-taking in banks. Erkens, Hung, and Matos (2012) analyze the influence of board independence and institutional ownership on the stock performance of a sample of 296 financial firms (also including insurance companies) in over 30 countries over the period 20072008. They find that banks with more independent boards and greater institutional ownership have lower stock returns. Kirkpatrick (2008) establishes that weak corporate governance in banks leads to inadequate risk management, especially insufficient risk monitoring through the board, a factor which contributed greatly to the bank instabilities during the crisis. ${ }^{4}$ 
Although the existing body of research has clearly established a connection between governance and bank risk taking behavior, these studies generally do not investigate the influence that certain governance characteristics have on bank failure. The risk variables most often investigated are the stock price (e.g., Beltratti and Stulz, 2012), returns (e.g., Gropp and Köhler, 2010), lending behavior (e.g., Gorton and Rosen, 1995), or general stability indicators, such as the Z-score (e.g., Laeven and Levine, 2009). Standard governance proxy variables are managerial shareholdings (e.g., Anderson and Fraser, 2000), bank insider shareholdings (Gorton and Rosen, 1995), the ownership percentage of the single largest shareholder (Beltratti and Stulz, 2012), or the shareholder friendliness of the board (as developed by Aggarwal et al., 2009, and used by e.g. Beltratti and Stulz, 2012).

Our paper offers three important contributions to the literature. We are the first to combine a range of these factors by investigating the influence the ownership and management structures in banks may have on their probability of failure. We are the first to differentiate between top- and lower-level management shareholdings as well as between outside and inside director shareholdings. Finally, our paper is the first to analyze the influences of management structure on bank failure probability.

\section{DATA}

\subsection{Sample Selection}

Our data set is comprised of two bank subsamples: 85 US-based and -held failed commercial banks in the period 2007:Q1-2010:Q3, and a control sample of 256 US-based and -held nonfailed commercial banks over the same period. To obtain the failure bank sample, we use the 
FDIC Failed Institutions list as reported by the FDIC. ${ }^{5}$ This list contains a detailed description of each failure of an FDIC-insured commercial bank or thrift, including the name of the bank, the exact date of failure (i.e., when the bank was put into FDIC conservatorship), its location, the estimated cost of the failure to the FDIC, as well as information on the acquiring institution or liquidation of the failed bank. The list allows us to compile the data set of all failed institutions which are eligible for the analyses in our paper. From 2007:Q1 to 2010:Q3, the list contains 295 banks which went into FDIC conservatorship. After excluding 46 failed thrifts, we obtain 249 commercial bank failures in our observation period. To obtain the control sample of non-failed banks, we start with the universe of all US-based and -held commercial banks in the period 2007:Q1 to 2010:Q3, leaving us with over 4,000 banks (excluding thrifts, merged banks, banks with charter changes). However, the scarce availability of reliable corporate governance data, which is pivotal for our analysis, reduces the sample sizes of failed and non-failed banks considerably.

We collect governance data on failed and non-failed banks from several sources: the Mergent bank database, the S\&P Capital IQ People Intelligence (PI) database, SEC filings publicly available through the SEC's EDGAR website, the FDIC Institutions data, and CRSP. The Mergent database contains detailed ownership information for 495 US commercial banks (both stock-listed and private). We specifically use information on each bank's shareholders, directors, and officers as well as on the lower-level managers. To expand the sample, we complement the Mergent database with the information given in share registration statements (S-1), statements of changes in ownership (S-4), annual reports (10-K filings) and proxy statements (DEF 14A) filed with the SEC of each bank with registered securities. ${ }^{6}$ The Capital IQ PI data provides us with information about the option holdings and compensation of directors, officers and lower level managers. The information on whether a bank is in a multibank holding company or not is taken 
from the FDIC Institutions data set, obtained through the official FDIC website. Additional information on trading and stock-listing is obtained from CRSP. TARP banks are both independent banks as well as those in BHCs that received TARP funds.

We construct our corporate governance data set by matching the Mergent bank data base as well as the Capital IQ PI (Cap IQ) data with our sample of failed banks, and a sample comprised of all non-failed banks in the US in our observation period. We use Mergent for all (share)-ownership data, and Cap IQ for all compensation data of CEOs, directors, as well as higher- and lower-level managers. For all four corporate insider groups, we therefore obtain job titles (Cap IQ), full shareholdings (Mergent), option holdings (Cap IQ), and full compensation details, including total compensation, option and stock awards, salary, cash bonus payments, and long-term incentives (Cap IQ). ${ }^{7}$ Whenever the given information from the matched databases is spotty or seems imprecise, we use information on the respective variable from SEC filings.

Following the matching procedure, our final sample of banks with corporate governance data consists of 85 failed banks (34 percent of the initial sample of failed banks) and 256 non-failed banks (6 percent of the initial sample of non-failed banks). Since some of our independent variables date back to 2006:Q1, we obtain a total of 6,152 bank-quarter observations over the period 2006:Q1-2010:Q3. ${ }^{8}$

As can be seen from these numbers, we obtain corporate governance data for a much larger fraction of failed than non-failed banks. This is because we deliberately put more effort into hand-collecting governance data for the failed banks, which is not always possible for the control sample because of its sheer size $(4,000+$ banks $)$. This might result in a potential sample selection bias, for which we control thoroughly in several robustness tests, as discussed in Section III B. 
Additional data are collected from seven different sources. We use the Federal Financial Institutions Examination Council (FFIEC) Call Report data set to collect bank balance sheet, income statement, and off-balance sheet data for each bank. ${ }^{9,10}$ These data are augmented by two additional data sets containing general economic indicators on the state level. The real estate price development is measured using the quarterly changes of the seasonally-adjusted Federal Housing Financing Agency (FHFA) house price index for the state. The quarterly percentage change in state GDP is taken from the Bureau of Economic Analysis. The fourth additional data set contains detailed information on the annual census-tract- or MSA (Metropolitan Statistical Area)-level mortgage lending in the United States. This data set is referred to as the "Home Mortgage Disclosure Act" or "HMDA" data set, obtained through the FFIEC. This data contains the total amount and volume of mortgage loans by year and census tract/MSA, both on an absolute level as well as broken down by borrower characteristics. We make use of this data set, along with the FDIC Summary of Deposits (SoD) dataset to measure banks' local markets' subprime exposure, a factor widely believed to have caused many of the problems of the recent financial crisis. $^{11}$

To gather additional anecdotal information on each failure, we use multiple sources. First, we employ the Material Loss Reports (MLRs) published by the FDIC as part of their bankruptcy procedure for all material bank failures. ${ }^{12}$ In it, the FDIC provides a detailed report on the causes for the failure of the bank, whether or not the failure was caused by the bank's management and its (lack of) risk management, and whether or not the failure could have been anticipated by the regulatory and supervisory authorities of the bank. We use one additional source to determine the surprise of each bank's failure: stability reports ("LACE Reports") published by Kroll Bond Ratings, an independent firm specialized in rating financial services firms. 
All additional data sets are merged with the main sample of failed and non-failed banks on a quarterly bank basis. A detailed description of all of the explanatory variables used in our analyses can be found in Table 1 .

(Table 1)

\subsection{Anecdotal Evidence on Bank Failures}

We first investigate the causes of bank failures on an anecdotal basis. We do so to understand better the different reasons for bank failures and to ensure that our sample of bank failures is not biased by too many cases of fraud or regulatory intervention. We draw on the Material Loss Reports (MLRs) and news sources to determine that the reasons for bank failures can be clustered into four distinct groups: "General Crisis Related," "Loan Losses Only," "Liquidity Problems and Loan Losses," and "Other." The MLRs reporting on the failures mentioned these four groups of failure reasons almost exclusively. If MLRs and other sources do not contain a specific failure reason we label the failure as "General Crisis Related." As shown in Table 2, Panel A, we find that 32 out of 85 banks fall into this category. If it is explicitly mentioned that either loan losses or a combination of loan losses and liquidity problems was the cause for the failure, we cluster the banks in the respective groups "Loan Losses Only," or "Liquidity Problems and Loan Losses." We find that 41 banks' failures were triggered by loan losses only and 11 banks failed after the occurrence of both liquidity problems and loan losses. Interestingly, no bank failed due to liquidity losses only. For one bank, a specific failure reason could not be determined, and the failure reason was not specifically linked to the crisis; we thus label their failure reason as "Other." These anecdotal results suggest that loan-induced losses played a crucial role for banks' stability during the recent financial crisis. 
(Table 2)

The FDIC also publishes the estimated cost of the failure to the FDIC insurance fund. We collect and report these numbers to show the economic importance and which failure types are the most costly. The overall estimated cost of all failures in our sample to the FDIC insurance fund is about $\$ 3.57$ billion. The most expensive quarter was 2009:Q4 with $\$ 1.35$ billion in losses caused by only 10 failures. The 41 loan loss-induced failures are the most costly group with a total of $\$ 1.84$ billion.

In a second step, we collect anecdotal evidence on the roles of the banks' management and regulatory actions prior to failure. Specifically, we determine whether or not bad risk management contributed to the failure and if bank regulators interfered with the management of a failing bank through cease-and-desist orders. Whenever the MLRs or other official FDIC releases mention that the bank suffered from managers' bad risk management, we classify the respective bank as a "Bad Risk Management" bank prior to failure. The information on cease-and-desist orders is taken from the MLR reports and cross-checked with data provided by the FDIC on cease-and-desist orders. Panel B in Table 2 shows $20 \%$ of all failures are deemed to have had bad risk management, and a third of all failed banks was subject to regulatory intervention through cease-and-desist orders prior to failure. These numbers suggest that bad risk management might have been a problem in a substantial fraction of failed banks, and that regulators were aware of problems and stepped in to try and solve these problems before failure.

Based on the MLRs and LACE ratings, we also find that only $7.06 \%$ of all bank failures came as a surprise and were neither anticipated by a rating agency nor by the supervisory authority. LACE rating reports contain a rating scheme for each bank (based on a number of standard rating indicators) ranging from $\mathrm{A}$ (best) to $\mathrm{F}$ (worst). As the ratings are published quarterly, we are able 
to determine whether or not a bank has a rating better than " $F$ " in the quarter prior to failure. We deem any failure as "surprising" if either the MLR specifically states that it was surprising or the LACE report shows that the failed bank's rating was better than " $F$ " in the quarter prior to failure.

\subsection{Corporate Governance and Bank Failures}

Table 3 shows summary statistics of the ownership, management and compensation data of our sample banks. To measure the influence of certain types of ownership, management, and compensation structures on bank failure probability, we cluster directors and managers in four distinct groups. The groups are displayed in Panel A of Table 3. The first group is comprised of outside directors - members of the board of directors who have no other role in their respective bank than being on the board. Chairman and Vice Chairman of the board can be included in this group if they meet the criteria, i.e. do not serve as an executive or work in any other capacity for the company. Panel A shows that this group is mostly comprised of regular board members (79.3\%), whereas outside Chairman and Vice Chairman only comprise $20.7 \%$. The second group is the CEO. As can be seen in Panel A, we include the CEO and co-CEOs in this group (79.1\%), as well as Presidents and co-Presidents (20.9\%). We include Presidents in the CEO group whenever a bank does not have a designated CEO but instead a President as acting Chief Executive Officer. Our third group comprises all higher-level managers except for the CEO. These are all managers with a 'Chief Officer' title, such as Chief Financial Officer or Chief Operating Officer, and therefore only executive-level managers. Panel A shows that Chief Financial Officers are most prominently represented in this group with $46.4 \%$, followed by Chief Lending Officers with 19.9\%, and Chief Operating Officers (15.9\%). Interestingly, Chief Risk Officers represent only $4.4 \%$ of the in-sample banks' higher-level management. This is a rather small percentage, perhaps suggesting that many banks do not award single chief officer positions 
for the head of risk management, or that the risk management is headed by another chief officer. ${ }^{13}$ Finally, the lower-level management group consists of managers who are not in the categories above. With $81.5 \%$, the most of this group is Vice Presidents, ${ }^{14}$ followed by department heads ${ }^{15}$ with $10.5 \%$, and corporate secretaries with $7 \%$. Treasurers only represent $0.9 \%$ of this group.

(Table 3)

Panel B reports ownership and compensation information about banks for which we have corporate governance data. Total numbers show that lower-level managers are the largest group with an average of about 20 individuals per bank, followed by outside directors with about 13 people. Each bank has about 4 non-CEO higher-level managers. Note that the mean number of CEOs per bank is $>1$ as some banks have two co-CEOs. The shareholdings show that, on average, outside directors hold the most overall shares with $9.5 \%$, followed by lower-level management with $5.7 \%$ and CEOs with $1.7 \%$. All other compensation components show the reverse picture: CEO have higher total option value, salary, bonus, option and stock awards, long-term incentives, and total compensation than the remaining three groups. CEOs have the highest total annual compensation with $\$ 1.95$ million, followed by non-CEO higher-level management with $\$ 801 \mathrm{~K}$, and lower-level managers with $\$ 708 \mathrm{~K}$. Directors only make $\$ 59 \mathrm{~K}$ annually, which is not surprising as these are mostly part-time positions.

Panel C shows the share and option ownership data for each of our four director- and managergroups by bank size. Generally, we see that ownership of all four groups is larger in smaller banks as compared to larger banks, likely because the latter have a more diverse ownership structure due to their size. This effect is least pronounced for higher-level management shareholdings, which remain fairly stable across the size buckets. 
Finally, Panel D reports the governance data broken down by failed and non-failed banks. The difference-in-means test shows that failed and non-failed banks differ significantly in ownership, compensation, and management structure. On average, the four observed groups of outside directors and managers hold significantly more shares in failed banks than in non-failed banks. Differences between the two bank groups can also be seen in the various compensation proxies. All four groups receive a significantly smaller fraction of their compensation in stock and option awards in failed banks, and both management groups except for the CEO also receive a significantly smaller annual bonus payment in failed banks. The same pattern of difference, however, is not mirrored in option holdings. Outside directors hold slightly fewer options in failed banks. Although the CEO holds on average more options in failed banks, there is no significant difference in the option holdings of higher- and lower-level management.

We also report information if the bank has publicly traded securities, if it received TARP funds, and if it is organized in a multibank holding company. We include these additional ownership factors because those banks might have access to additional capital which serves as a source of financial strength. The numbers show that failed banks less often received TARP funds, are more likely to be public, and are more frequently part of a multibank holding company, as compared to non-failed banks. Finally, we see that failed and non-failed banks differ in their management structures only with regard to the fraction of non-CEO higher-level managers, board size and the frequency with which the Chairman of the board is also CEO. The fraction of higher-level managers is significantly higher in failed banks, whereas the board size and the chances of the CEO being also Chairman of the board are significantly less.

The presented numbers are merely descriptive, so their interpretations can only be tentative. However, they suggest two things. First, failed and non-failed banks differ strongly in the way 
their management structures are set up. Whereas failed banks have more non-CEO chief officers, they have smaller boards and more separation between Chairman and CEO positions. Second, the numbers strongly suggest that incentive structures are chosen differently in both groups. Failed banks have stronger inside share ownership of higher- and lower-level managers, as well as directors. The compensation packages for all directors and manager groups are also different. The awarded stocks and options are much lower in failed banks, as are the bonus payments for nonCEO managers. Judging from the descriptive numbers alone, higher shareholdings and lower variable compensation seem to make banks riskier. These patterns are analyzed in more detail in a multivariate setting in part III.

\subsection{Summary Statistics of Accounting, Competition, Economic, and Regulatory Variables}

Table 4 provides summary statistics on the other variables in our analysis. It shows that failed banks differ strongly from non-failed banks, especially in terms of general characteristics, business focus, and overall stability. Failed banks are on average smaller than non-failed banks, have lower capital ratios, lower total loan volume relative to their assets, but a larger fraction of construction and development (C\&D) loans, stronger loan growth as well as weaker loan diversification as measured by the loan-concentration Herfindahl Hirschman Index (HHI). On the funding side, failed banks rely more on brokered deposits and less on retail deposits. Not surprising, failed banks also perform worse in terms of overall stability: they have a negative average return on assets and a much higher non-performing loan ratio. Interestingly, failed banks have a lower exposure to mortgage-backed securities (MBS) than non-failed banks.

(Table 4) 
For market competition, we report the deposit-based HHI of market concentration and the subprime lending ratio of originated subprime mortgage loans to total originated mortgage loans on the census tract or MSA level. ${ }^{16}$ The HHI is based on the FDIC Summary of Deposits data on the branch level. We use each bank's share of deposits by branch in each MSA or rural county market for these calculations, and take weighted averages across markets for banks in multiple local markets using the proportions of total deposits as the weights. ${ }^{17}$

The state economic condition variables include the house price inflation indicator, calculated using the average quarterly changes of the seasonally-adjusted Federal Housing Financing Agency (FHFA) house price index for the bank's states, and the quarterly percentage changes in

state GDP. ${ }^{18}$ Comparing the values for failed and non-failed banks, we find that failed banks face slightly lower market concentration, lower subprime exposure, a steeper decrease in house price values, and a slightly lower GDP growth than non-failed banks. Finally, we observe that $27.26 \%$ of our banks are supervised by the OCC and $19.5 \%$ by the FED. The remaining $53.25 \%$ are supervised by the FDIC.

\section{MULTIVARIATE ANALYSIS}

\subsection{Methodology}

We use a multivariate logistic regression framework to investigate the factors that affect bank failure. The models and its results are presented in Table 5. We run two main models. First, we run a multivariate logistic regression model with a $0 / 1$ indicator for bank failure as dependent variable (model I). We follow a broad body of literature having established this approach as standard procedure (e.g., Campbell, Hilscher, and Szilagyi, 2008), which was pioneered for banks 
by Martin (1977). We include five sets of explanatory variables: corporate governance variables, accounting variables, market competition measures, state economic indicators, and regulatory variables. For all analyses, we include our main sample of 85 failed banks and 256 non-failed banks. We run each model three times, once each with the exogenous variables measured one year immediately preceding the failure, two years prior to failure, and in the fixed period of 2006:Q4. ${ }^{19}$ By testing the time component, we follow a body of research (e.g., Cole and Gunther, 1998; Cole and White, 2012) which shows that the predictive power of binary regression models in the context of bank failures varies over time. Including regression models using variables only from 2006:Q4 allows for measurement of the effects with variables not having been influenced by any impact of the financial crisis. ${ }^{20}$

The corporate governance variables are taken from the set of measures introduced above. To account for the bank's ownership structure, we include the shares held by the four groups of directors and managers (defined as in Section II C). Each is standardized by the number of shares outstanding of the respective bank. We choose this combination of variables based on the existing literature which shows that shareholdings of directors and managers can have substantial influence on bank risk-taking, such as Saunders, Strock and Travlos (1990), Sullivan and Spong (2007), Anderson and Fraser (2000), Gropp and Köhler (2010), and Ellul and Yerramilli (2013). Since managerial shareholdings affect bank risk-taking, they may also be relevant for a bank's likelihood of failure. To control for all 'ownership' stakes in the bank, we also include option holdings (scaled with total assets to control for size effects) ${ }^{21}$ of all managers and directors.

By including the full compensation structure, including stock and option awards, we account for the body of literature showing the strong influence compensation can have on bank risk. Examples are Mehran and Rosenberg (2008) who analyze CEO stock options, Cornett, McNutt 
and Tehranian (2009) who analyze executive and director ownership, Bhattacharyya and Purnanandam (2012) who analyze CEO compensation structures, bonus payments and compensation sensitivity to bank earnings, Fahlenbrach and Stulz (2011) who analyze cash bonuses, as well as option and stock compensation of bank CEOs and top-level non-CEO executives, Chu and Ma (2015) who analyze the influence of stock option grants on mortgage lending, as well as Cheng, Hong, and Scheinkman (2015) who analyze the combination of all single compensation components as the total compensation of a bank's top 5 executives. ${ }^{22}$ Note that stock and options awards as well as bonus payments are lagged by one year to account for the fact that these compensation components are always decided on based on managers previous' year's performance and expected as such (based on Fahlenbrach and Stulz, 2011). Note also that two other popular proxies for executive compensation structures in banks are pay-risk sensitivity, or 'vega,' and pay-performance sensitivity, or 'delta,' as used by e.g. DeYoung, Peng and Yan (2013). Vega measures the recipient's change in wealth in reaction to a change in the employer's stock volatility, delta measures the change in wealth to stock performance. However, due to the fact that we also observe banks without publicly traded stock we cannot use these measures to proxy for compensation structure.

We also include a dummy indicating whether the bank received TARP funds, and dummies for whether a bank is in a multibank holding company, ${ }^{23}$ and whether the bank or its BHC is a public bank.

To proxy for management structures, we include the number of outside directors, the number of chief officers, and the number of lower-level managers, all scaled by the bank's board size. ${ }^{24}$ We additionally employ the log of the number of members of the board of directors ("Board Size") and an indicator if the CEO of the bank is also its Chairman. We choose these variables based on 
prior literature which shows that bank management structures, and especially board composition, are paramount for bank risk-taking. DeYoung, Peng and Yan (2013) show that banks' boards can step in to mitigate their CEOs' risk-taking incentives and therefore might play a very active role in the risk-taking decisions of a bank. Since a bank's board decisions are most likely driven by its composition, our chosen management structure variables are meant to capture this composition. Specifically, we focus on board independence, CEO influence, and size. Pathan (2009) shows that smaller boards, in which outside shareholder interests are represented better and in which the CEO has less power, have a positive influence on bank risk. Beltratti and Stulz (2012) show that the shareholder friendliness of the board, of which board independence is a crucial part, can have an influence on bank performance. Gorton and Rosen (1995) show that entrenched managers may take on excessive risks in banking. Although their paper focuses on outside control through other shareholders, we believe it might apply to all kinds of outside control, also through e.g. an independent board of directors or the size of the management committee. Ellul and Yerramilli (2013) confirm the importance of both board independence and managerial entrenchment for bank risk. They show that both factors can determine a bank's risk management system, which in turn has an impact on bank riskiness. Jointly, our proxy variables should therefore capture the effects single management structure factors should have on bank failure probability.

We include accounting variables which have been included in virtually all prior failure models (e.g., Lane, Looney, and Wansley, 1986; Whalen and Thomson, 1988; Espahbodi, 1991; Logan, 1991; Thomson, 1991; Cole and Gunther, 1995, 1998; Kolari et al., 2002; Schaeck, 2008; Cole and White, 2012). We include measures of the bank's size, return on assets, capitalization, loan portfolio composition, funding structure, securities business, and off-balance sheet activities. By including the log of total assets, the ratio of equity to assets, and the return on assets, we follow Cole and Gunther (1995, 1998), Molina (2002) and others who show that these variables can 
serve as valid indicators for size, capitalization, and profitability. To measure the composition and stability of the bank's loan portfolio, we include the ratio of total loans excluding construction and development (C\&D) loans to total assets, as well as the ratio of C\&D loans only to total assets. This follows Cole and White (2012), who show that C\&D loans have strong explanatory power in predicting bank failures, especially in the recent financial crisis. We also include a loan concentration index, the growth of a bank's loan portfolio, and the ratio of nonperforming loans to total loans to account for portfolio concentration and credit risk. Short-term funding and illiquidity risks are measured by the ratios of short-term deposits to assets and brokered deposits to assets. We additionally include the ratio of mortgage-backed securities (MBS) to assets. Finally, the ratio of unused commitments to assets is included as a measure of off-balance sheet risks. ${ }^{25}$

The variables on bank competition contains the HHI of bank local market power on the MSA or rural county level, its squared value, as well as the ratio of originated subprime mortgage loans to total mortgage loans originated on census tract/MSA level. We use the HHI and its square to proxy for the competition a bank faces in its local market, which could have positive, negative, or non-monotonic effects. ${ }^{26}$ We also include the average subprime mortgage loan ratio in a bank's census tract or MSA to measure the impairment of each bank's local market competitors. The variables on state economic conditions contains the FHFA house price inflation to account for another real estate-related factor of the crisis: the decline in house prices. We also include the annual percentage change in state GDP as a measure for the macroeconomic conditions faced by the bank. 
Our fifth set of variables controls for potential differences in bank stability which could be explained by a bank's primary federal regulator. For this purpose, we include OCC and Federal Reserve dummies, with FDIC-regulated banks as the base case.

The second model we run (model II) is a Heckman Selection model using a two-stage probit regression setup. The goal is to validate the results of the regular logit regression model by accounting for possible selection biases due to different availability of corporate governance data. Cole, McKenzie, and White (1995) show that this model can serve as a valid control tool for binary regression models testing bank failures. Our main concern is that only specific types of banks with certain ownership and management structures report their corporate governance data, so that our analysis would suffer from a non-random subsample of banks. We include a number of instruments in the selection equation. These are the size of the bank and its squared value to account for nonlinearities in size, because very large banks may have a much higher probability of publishing corporate governance data. We also use the indicator variable for whether banks are 'public' because, as mentioned before, these banks are required by the SEC to publish their corporate governance structure. We additionally include if banks are organized in a multibank holding company because these banks might have a higher probability of publishing their corporate governance data. ${ }^{27}$ Furthermore, we include the individual fractions of a bank's loan portfolio (real estate, agricultural, commercial and industrial, and individual loans) in our set of instruments to account for banks' different foci in business. We also include the cumulative operating income of the bank from 2004:Q1 to 2006:Q4 as banks with high profits and accordingly much good news might also have a higher likelihood of publishing governance information. Corporate governance reporting may also differ by regulatory authorities, so we include the regulatory dummies. Finally, we incorporate past accounting variables of the bank. These are the quarterly averages from 2004:Q1 until 2006:Q4 of asset growth, change in capital 
ratio, growth of total loans excluding $C \& D$ loans, growth of $C \& D$ loans, change in loan concentration, short-term deposits growth, brokered deposits growth, return on assets, nonperforming loans growth, mortgage-backed securities growth, and unused commitments growth. $^{28}$ Note that we cannot include the regression for 2006:Q4 due to insufficient observations.

\subsection{Main Results}

Starting with the share- and option ownership data presented in Panel A of Table 5, we find two striking patterns which mirror the descriptive results presented in Section II C. Shareholdings of non-CEO higher-level managers and lower-level managers significantly increase failure probability. This result holds in all three periods in both the main and the $2^{\text {nd }}$ stage of the Heckman selection model. Apparently, higher shareholdings of non-CEOs increase a bank's risk. The magnitudes of the effects are also economically meaningful. Marginal effects calculated from the Heckman model show that the probability of failure increases by 5.4 (3.9) percentage points when ownership of lower-level management (non-CEO higher-level management) doubles, ${ }^{29}$ suggesting that non-CEO lower- and higher-level managers tend to increase risk taking when they have large stakes in the bank. As discussed above, one potential explanation is that the non-CEO management shareholders behave according to the moral hazard incentive for insured bank shareholders as in Merton (1977). ${ }^{30}$ The risk-taking incentive may be less for CEOs because they are publicly known figureheads of a bank and are most likely to be vilified in the event of failure, whereas other managers are more anonymous and in better positions to obtain comparable employment. $^{31}$

(Table 5) 
Interestingly, this pattern cannot be seen for option holdings or the remaining compensation variables. The only compensation variable which supports this pattern is the fraction of annual (cash-) bonus payments right before the onset of the financial crisis in 2006:Q4 for higher- and lower-level managers. The higher the fraction of expected bonus payments to total compensation, the higher was the probability of failure of the respective banks. This is perhaps unsurprising. If a compensation package allows for a large fraction of variable cash payments, there is a large upside for risk-taking for the recipient.

Finally, the negative influence of the TARP dummy on bank instability suggests that obtaining TARP funding either protected banks or that mainly high-quality banks received TARP funding.

In contrast to the strong results for the ownership variables, the management variables do not have substantial explanatory power. None of our five main management variables seems to have a substantial influence on a bank's probability of failure across different model specifications. We only find weak significance for some of these variables scattered in different model specifications. Accordingly, we conclude that the management structure of a given bank is not decisive for its overall stability.

We find the differences in the accounting variables between failed and non-failed banks in the descriptive statistics to be largely confirmed in our multivariate analysis. The capital ratio has predictive power mostly one year before failure, whereas the return on assets is strongly and significantly linked to failure probability in every model specification. The findings for these two variables are intuitive as they are the main ingredients of the bank's distance to failure (e.g., Laeven and Levine, 2009; Houston et al., 2010). The summary statistics for the NPL ratio are also confirmed in the regression models. The NPL ratio has a significantly positive influence on the probability of failure. Our descriptive statistics above also show that failed banks rely to a 
larger extent on wholesale funding in terms of brokered deposits. We also find this to be a significant influence for failure probability in our multivariate analyses. The other main funding source, short-term deposits, exhibits significantly negative coefficients across most model specifications, implying that more short-term deposits reduce failure probability. These results confirm the findings of Gatev, Schuermann, and Strahan (2006), who show that transaction deposits are sticky and can accordingly be considered as a stable funding source. Finally, we also verify the importance of $C \& D$ loans in increasing the probability of bank failure as in Cole and White (2012). We do not find asset size, loan exposure, loan portfolio concentration, or the amount of MBS to have any consistent or strong influence on a bank's failure probability across different model specifications.

Looking at the last three sets of variables, we first find that the local market power of the bank seems to have only a weakly positive influence on bank stability. Second, we observe that high exposures of the bank's competitors to subprime mortgage loans have positive effects for the bank under analysis. This is intuitive as these direct competitors might suffer from high loan default rates and compete less aggressively. Our two state economic indicators seem to influence failure probability. The house price inflation has a negative effect, mostly two years before failure, while the GDP growth variable shows significantly negative values mostly in the year before failure. These results suggest that declining real estate prices and negative GDP growth increase the chances for a bank to fail. Finally, the OCC dummy seems to have a slightly positive influence on bank instability, suggesting that, other things equal, nationally chartered banks have higher failure probabilities (also found by Cole and White, 2012).

We also re-run both analyses from Panel A with the dollar value in share and option ownership as explanatory variables, instead of the ratios of shareholdings to total shares and option holdings to 
total assets. Results are shown in Panel B of Table 5. This analysis accounts for the effect the full dollar value of a portfolio of stocks or options might have on the risk-taking behavior of bank employees and potential distortions due to the normalization with asset size. We thereby follow Hall and Liebman (1998), Core and Guay (1999), and Fahlenbrach and Stulz (2011) who argue that the primary incentives for CEOs stem from the dollar value of their portfolios instead of the annual stock and option grants, a result also seen in our analyses. Panel B of Table 5 confirms the results of our main analysis. The dollar values of the shareholdings of non-CEO management have a significant and positive coefficient, whereas the dollar value of the option holdings are insignificant. Only the CEOs' option holdings 2 years before failure have significant coefficients, a result we do not see in Panel A's analysis.

We run several robustness tests, which are shown in the online appendix. First, we exclude systemically important financial institutions (SIFIs) with assets over $\$ 50$ billion, as these may exhibit very different business models as well as substantially different degrees of government support and regulation and supervision. We also exclude multibank holding companies due to the aforementioned internal capital markets and the source of strength these might provide to the banks. Furthermore, we exclude banks that received TARP funds that may affect their failure probabilities. Our results remain unchanged in all subsamples. In addition, we include all banks irrespective of whether corporate governance information is available to observe the consistency of variables between samples. This results in a sample of approximately 2,000 banks as we do not have all observations available for banks' subprime loan exposure due to our rigorous data selection procedure. Parsimonious models as well as models with differently specified accounting variables are also tested. Finally, we use the total number of shares as a different standardization measure for option holdings and exclude variable compensation components from our set of 
explanatory variables as they might ultimately lead to share- and option holdings. All results confirm our main findings.

\section{ADDITIONAL ANALYSES: BANK CHARACTERISTICS AND RISK-TAKING CHANNELS}

We run two additional analyses to help us better understand the dynamics behind the effects of corporate governance on banks' probability of failure. First, we test if some types of banks are more prone to be influenced in their failure probability by certain corporate governance structures than others. We use three main proxies to distinguish different types of banks: first, a dummy indicating if a bank's CEO is also its Chairman, i.e. CEO duality. Second, a size variable to divide our sample by asset size. The variable takes the value of 1 for all banks with assets smaller than the $25^{\text {th }}$ percentile of the total asset size of banks in our sample. Third, we control for nonpublic banks through an indicator which is 1 if the respective bank has no publicly traded securities. These indicators should separate banks with a more closely held governance structure in which much power is concentrated in a CEO's hands from those with more decentralized power. The first variable measures this directly whereas the latter two variables capture the broader ownership and governance structure of banks. By including those variations of characteristics and size, we hope to distinguish smaller, privately-held banks with a perhaps more closely-held ownership structure from larger and public banks, with more diverse ownership structures, more hierarchical layers of management, and perhaps more complex operations.

As shown in Table 6, we re-run our logit model specification of Table 5, with the exception that we include interaction terms of our main director- and management group shareholdings with the 
three bank characteristic indicators. The interaction terms in all model specifications show that the effects of non-CEO higher-level and lower-level management shareholdings only apply to larger and publicly traded banks. This is perhaps unsurprising as oversight over risk-taking decisions of lower-level managers might be limited in larger institutions. Also, lower-level managers might have more discretion over actual risk-taking decisions in larger institutions, allowing them to take risks within their job responsibilities without their superiors being aware of these risks. Interestingly, we also see the result for banks without CEO duality. Usually, the separation of Chairman and CEO roles is an indicator of good governance, alleviating agency costs and increasing supervision. However, in our sample this does not seem to be the case, as we see that failed banks have more frequent separation of the CEO-Chairman positions than nonfailed banks. This may suggests one or both of two things. First, CEO-Chairmen muted risktaking in their banks due to their heightened visibility as major representatives of both the board of directors and the executive committee, consistent with our argument of public vilification in the event of default. Second, non-CEO Chairmen unknowingly and unintentionally allowed for greater risk-taking because they did not understand the potentially complex inner workings of the risk their bank was taking during the crisis, so they were unable to perform their supervisory duty. This argument finds support by the fact that, as shown in the next robustness test presented below, risk-taking was indeed complex.

\section{(Table 6)}

As the specific channel of bank risk-taking is indeed of great importance, we analyze it in a separate test. We choose five distinct indicators for bank risk: the capital ratio, ratio of nonperforming loans (NPLs) to total assets, natural log of the Z-Score, return on assets, and ratio of non-interest income to total assets. We choose this combination of risk channel variables because 
prior literature has established them as relevant proxies for the operating and strategic business of a bank which also influence bank risk (e.g., Thomson, 1991, 1992; Cole, 1993; Cole and Gunther, 1995, 1998; Laeven and Levine, 2009; Houston et al., 2010; Cole and White, 2012; Beltratti and Stulz, 2012; and Berger and Bouwman, 2013). As DeYoung and Torna (2013), and DeYoung, Peng and Torna (2013) show that non-interest income is strongly influenced by CEO compensation and can be a most relevant factor for bank failure, we include it as well as a major risk-taking channel.

Panel A of Table 7 shows summary statistics of the five risk variables for failed and non-failed banks over the period 2004 to 2010. Interestingly, we detect that failed banks had higher capital ratios, lower NPL ratios, and no worse Z-Scores than non-failed banks in the period leading up to the financial crisis. Only return on assets and the fraction of non-interest income was significantly lower in failed banks. This picture reversed during the financial crisis, however, when NPL ratios spiked, capital became depleted, return on assets turned negative, and the Z-Score consequently dropped below zero in failed banks.

\section{(Table 7)}

In Panel B of Table 7, we report results of multivariate cross-sectional regression models, using the five risk-channel indicators as dependent variables. However, instead of using the actual indicators as dependent variables, we use the first four moments plus the most extreme (positive or negative) 'bad' value of their distribution. Model I has the mean of each risk-channel indicator as dependent variables, model II the standard deviation, model III the skewness, model IV the (excess) kurtosis, and model $\mathrm{V}$ the most extreme 'bad' value (positive or negative) of the distribution. We use these five distributional characteristics to test which component of each indicator is actually influenced by a bank's governance characteristics, such as tail risk (skewness 
and kurtosis, tested in models III and IV) as suggested by Ellul and Yerramilli (2013) or volatility (standard deviation, tested in model II). This allows for a more detailed understanding of the risks taken through incentivization.

The first main result is that neither share nor option ownership of the CEO seem to have any strong or persistent influence on any of the indicators' moments. This confirms the results of our main analysis, in which we show that CEO compensation or ownership has no observable influence on failure probability. Second, we find that share ownership of non-CEO higher-level management has some influence on the observed risk-taking channels. Changes in capital ratios are overall more negative (mean) and tend to have more negative and fat tails (skewness and kurtosis) when shareholdings of non-CEO chief officers are higher. Also, NPL ratios are higher (mean) and have a stronger volatility (standard deviation), and return on assets are lower (mean) with a stronger volatility (standard deviation) and have more extreme and negative values (skewness, kurtosis, extreme values). Third, we find that share- and option holdings of lowerlevel management have overall little influence on changes in capital, NPL ratios, Z-Scores and return on assets. However, we do find that both (negative) skewness and (positive) kurtosis of the fraction of non-interest income are significantly and negatively related to lower-level management shareholdings. This suggests that banks in which lower-level managers hold more shares have higher tail risk in non-interest income. This result can be related to findings by DeYoung and Torna (2013), who find that non-interest income bank activities - stakeholder activities, as they call them, such as investment banking, venture capital activities etc. significantly increase failure probabilities of distressed banks. Activities in non-traditional banking activities therefore seem to be a strongly featured risk channel for bank managers if they are given risk-taking incentives through their compensation and ownership in the bank. 
Finally, we see that share- and option holdings of outside directors have some influence on some distributional characteristics of our risk-channel indicators. However, we detect no striking pattern: higher outside director shareholdings correlate negatively with the skewness of the change in capital ratio, and positively with mean and standard deviation of the NPL ratio. The NPL ratio also has a stronger positive skewness and kurtosis, indicating higher tail risk, in banks with more outside director option holdings. More outside director option holdings also benefit the Z-Score, which is higher and has lower volatility in these cases.

Overall, these results confirm and refine our results from Table 5. We see that the main influence on bank risk is not exercised by the CEO, but instead by non-CEO higher-level management and lower-level management. Also, we now understand that the primary channels through which risk is taken by these management groups are high and volatile NPL ratios, low and volatile return on assets and, especially in the case of lower-level management, tail risk in non-interest income.

\section{CONCLUSION}

This paper analyzes the roles of corporate governance in bank failures during the recent financial crisis. To do so, it examines the ownership, management and compensation structures of failed and non-failed commercial banks in the US. Our findings illustrate that a bank's ownership structure plays a substantial role in explaining likelihood of failure: banks are more likely to fail if they have more shareholdings of lower-level managers, such as Vice Presidents or department heads, and more shareholdings of non-CEO higher-level managers, such as Chief Financial or Chief Operating Officers. Shareholdings of CEOs do not increase risk of failure. These results are robust to the inclusion of a large number of other control variables, such as accounting-based 
performance ratios, competition, subprime exposures, and regulatory effects. We believe that these perhaps unexpected findings are rooted in moral hazard problems. Non-CEO managers with larger shareholdings may take on more risk to increase the value of their shares. CEOs would face the same incentives as shareholders, but are vilified in the event of a failure, so that the moral hazard problem and the connected risk-taking appetite may be curbed.

The study therefore offers important policy implications which might assist regulators, supervisors, managers, and other market participants in anticipating and preventing future banking crises. In addition to accounting variables indicating bank stability, such as capitalization, profitability, and non-performing loans, strong emphasis should be given to the analysis of the bank's corporate governance, especially the share ownership of its employees.

\section{References}

Adams, Renée Birgit. (2012) "Governance and the Financial Crisis." International Review of Finance 12(1), 7-38.

Agarwal, Sumit, and Itzhak Ben-David. (2014) "Do Loan Officers' Incentives Lead to Lax Lending Standards?” NBER Working Paper No. 19945.

Aggarwal, Reena, Isil Erel, René M. Stulz, and Rohan Williamson. (2009) "Differences in governance practices between US and foreign firms: measurement, causes, and consequences." The Review of Financial Studies 22(8), 3131-3169.

Anderson, Ronald C., and Donald R. Fraser. (2000) "Corporate control, bank risk taking and the health of the banking industry." Journal of Banking \& Finance 24(8), 1383-1398. 
Aubuchon, Craig P., and David C. Wheelock. (2010) "The geographic distribution and characteristics of US bank failures, 2007-2010: Do bank failures still reflect local economic conditions?” Federal Reserve Bank of St. Louis Review 92(05), 395-415.

Bebchuk, Lucian A., and Holger Spamann. (2010) "Regulating bankers' pay." Georgetown Law Journal 98(2), 247-287.

Beltratti, Andrea, and René M. Stulz. (2012) "The credit crisis around the globe: why did some banks perform better?” Journal of Financial Economics 105(1), 1-17.

Berger, Allen N., and Christa H.S. Bouwman. (2013) "How does capital affect bank performance during financial crises?" Journal of Financial Economics 109, 146-176.

Berger, Allen N., Leora F. Klapper, and Rima Turk-Ariss. (2009) "Bank competition and financial stability." Journal of Financial Services Research, 35, 99-118.

Bhattacharyya, Sugato, and Amiyatosh Purnanandam. (2012) "Risk-taking by banks: What did we know and when did we know it?" Manuscript.

Boyd, John H., and Gianni De Nicoló. (2005) “The theory of bank risk taking and competition revisited." The Journal of Finance 60(3), 1329-1343.

Boyd, John H., Gianni De Nicoló, and Abu M. Jalal. (2006) "Bank risk taking and competition revisited: New theory and evidence.” IMF Working paper, WP/06/297.

Campbell, John Y., Jens Hilscher, and Jan Szilagyi. (2008) "In search of distress risk." The Journal of Finance 63(6), 2899-2939.

Cannella, Albert A., Donald R. Fraser, and D. Scott Lee. (1995) "Firm failure and managerial labor markets - Evidence from Texas banking.” Journal of Financial Economics 38(2), $185-210$.

Caprio, Gerard, Luc Laeven, and Ross Levine. (2007) “Governance and bank valuation.” Journal of Financial Intermediation 16, 584-617. 
Carletti, Elena, and Philipp Hartmann. (2003) “Competition and financial stability: What's special about banking?" In: Monetary history, exchange rates and financial markets: Essays in honour of Charles Goodhart, Vol. 2, edited by P. Mizen, Cheltenham, UK: Edward Elgar.

Chu, Yongqiang, and Tao Ma. (2015) "How Does Executive Compensation Affect Bank Risk Taking: Evidence from FAS 123R.” Manuscript.

Cole, Rebel A., and George W. Fenn. (2008) "The role of commercial real estate investments in the banking crisis of 1985-92.” Manuscript.

Cole, Rebel A., and Jeffery W. Gunther. (1995) "Separating the timing and likelihood of bank failure.” Journal of Banking \& Finance 19(6), 1073-1089.

Cole, Rebel A., and Jeffery W. Gunther. (1998) "Predicting bank failures: A comparison of onand off-site monitoring systems.” Journal of Financial Services Research 13(2), 103-117.

Cole, Rebel A., Joseph A. McKenzie, and Lawrence J. White. (1995) “Deregulation gone awry: Moral hazard in the savings and loan industry." In The Causes and Costs of Depository Institution Failures, edited by Cottrell, Allin F., Michael S. Lawlor, and John H. Wood.

Cole, Rebel A., and Lawrence J. White. (2012) "Déjà Vu all over again: The causes of US commercial bank failures this time around." Journal of Financial Services Research 42(1), 5-29.

Core, John, and Wayne Guay. (1999) "The use of equity grants to manage optimal equity incentive levels." Journal of Accounting and Economics 28(2), 151-184.

Cziraki, Peter. (2014) "Trading by Bank Insiders Before and During the 2007-2008 Financial Crisis." Manuscript.

De Nicoló, Gianni, and Elena Loukoianova. (2007) "Bank ownership, market structure, and risk." International Monetary Fund Working Paper 07/215, Washington, D.C. 
Demsetz, Rebecca S., Marc R. Saidenberg, and Philip E. Strahan. (1996) "Banks with something to lose: The disciplinary role of franchise value." Federal Reserve Bank of New York Economic Policy Review 2(2), 1-14.

DeYoung, Robert, Emma Y. Peng, and Meng Yan. (2013) "Executive compensation and business policy choices at US commercial banks." Journal of Financial and Quantitative Analysis 48(01), 165-196.

DeYoung, Robert, and Gokhan Torna. (2013) "Nontraditional Banking Activities and Bank Failures During the Financial Crisis." Journal of Financial Intermediation 22(3), 397421.

Ellul, Andrew, and Vijay Yerramilli. (2013) "Stronger Risk Controls, Lower Risk: Evidence from U.S. Bank Holding Companies.” Journal of Finance 68(5), 1757-1803.

Erkens, David H., Mingyi Hung, and Pedro Matos. (2012) "Corporate governance in the 20072008 financial crisis: Evidence from financial institutions worldwide." Journal of Corporate Finance 18(1), 389-411.

Espahbodi, Pouran. (1991) "Identification of problem banks and binary choice models." Journal of Banking \& Finance 15(1), 53-71.

Fahlenbrach, Rüdiger, and René M. Stulz. (2011) "Bank CEO incentives and the credit crisis." Journal of Financial Economics 99(1), 11-26.

Financial Crisis Inquiry Report. (2011) "Final report of the National Commission on the Causes of the Financial and Economic Crisis in the United States." Official Government Edition, US Government Printing Office, Washington, D.C.

Gatev, Evan, Til Schuermann, and Philip E. Strahan. (2006) "Managing bank liquidity risk: How deposit-loan synergies vary with market conditions." The Review of Financial Studies 22(3), 995-1020. 
Gorton, Gary, and Richard Rosen. (1995) "Corporate control, portfolio choice, and the decline of banking." The Journal of Finance 50(5), 1377-1420.

Gropp, Reint, and Matthias Köhler. (2010) "Bank owners or bank managers: Who is keen on risk? Evidence from the financial crisis." Centre for European Economic Research Discussion Paper No. 10-013, 1-36.

Group of Thirty (G30) Corporate Governance Working Group. (2012) "Toward Effective Governance of Financial Institutions.” Washington , D.C., 2012.

Hall, Brian J., and Jeffrey B. Liebman. (1998) “Are CEOs really paid like bureaucrats?” The Quarterly Journal of Economics 113(3), 653-691.

Heckman, James J. (1979) "Sample selection bias as a specification error.” Econometrica 47(1), $153-161$.

Hellmann, Thomas F., Kevin C. Murdock, and Joseph E. Stiglitz. (2000) "Liberalization, moral hazard in banking and prudential regulation: are capital requirements enough?" American Economic Review 90(1), 147-165.

Helwege, Jean. (1996) "Determinants of Savings and Loan failures: Estimates of a time-varying proportional hazard function.” Journal of Financial Services Research 10(4), 373-392.

Hirshleifer, David, and Anjan V. Thakor. (1992) "Corporate Control Through Board Dismissals and Takeovers.” Journal of Economics \& Management Strategy 7(4), 489-520.

Holmstrom, Bengt, and Joan Ricart I Costa. (1986) "Managerial Incentives and Capital Management." The Quarterly Journal of Economics 101(4), 835-860.

Hong, Han, Jing-Zhi Huang, and Deming Wu. (2014) "The Information Content of Basel III Liquidity Risk Measures.” Journal of Financial Stability 15(1), 91-111

Houston, Joel F., Chen Lin, Ping Lin, and Yue Ma. (2010) "Creditor rights, information sharing, and bank risk taking." Journal of Financial Economics 96(3), 485-512. 
Huber, Peter J. (1967) "The behavior of maximum likelihood estimates under nonstandard conditions." Proceeds of the Fifth Berkeley Symposium on Maths, Statistics and Probability Vol. 1, 221-233.

Jiménez, Gabriel, Jose A. Lopez, and Jesús Saurina. (2013) "How does competition impact bank risk taking?” Journal of Financial Stability 9, 185-195.

Keeley, Michael C. (1990) "Deposit insurance, risk and market power in banking." American Economic Review 80(5), 1183-1200.

Kirkpatrick, Grant. (2009) "The corporate governance lessons from the financial crisis." OECD Financial Market Trends 2009/1, 1-30.

Kolari, James, Dennis Glennon, Hwan Shin, and Michele Caputo. (2002) "Predicting large US commercial bank failures." Journal of Economics and Business 54(4), 361-387.

Laeven, Luc, and Ross Levine. (2009) "Bank governance, regulation and risk taking.” Journal of Financial Economics 93(2), 259-275.

Lane, William R., Stephen W. Looney, and James W. Wansley. (1986) “An application of the Cox Proportional Hazards Model to bank failure.” Journal of Banking \& Finance 10(4), $511-531$

Logan, Andrew. (2001) “The United Kingdom's small banks' crisis of the early 1990s: what were the leading indicators of failure?” Bank of England Working Paper 139.

Marcus, Alan J. (1984) “Deregulation and bank financial policy.” Journal of Banking \& Finance $8(4), 557-565$.

Martin, Daniel. (1977) "Early warning of bank failure: A logit regression approach.” Journal of Banking \& Finance 1(3), 249-276.

Martinez-Miera, David, and Rafael Repullo. (2010) "Does competition reduce the risk of bank failure?" The Review of Financial Studies 23(10), 3638-3664. 
Mehran, Hamid, Alan Morrison, and Joel Shapiro. (2011) "Corporate governance and banks: What have we learned from the financial crisis?" Federal Reserve Bank of New York Staff Report No. 502, 1-42.

Meyer, Paul A., and Howard W. Pfifer. (1970) "Prediction of bank failures." The Journal of Finance 25(4), 853-868.

Merton, Robert C. (1977) "An analytic derivation of the cost of deposit insurance and loan guarantees: An application of modern option pricing theory." Journal of Banking \& Finance 1(1), 3-11.

Molina, Carlos A. (2002) "Predicting bank failures using a hazard model: the Venezuelan banking crisis." Emerging Markets Review 3(1), 31-50.

Ng, Jeffrey, and Sugata Roychowdhury. (2014) "Do loan loss reserves behave like capital? Evidence from recent bank failures." Review of Accounting Studies 19, 1234-1279.

Organisation for Economic Co-operation and Development (OECD). (2009) "Corporate governance and the financial crisis: Key findings and main messages." OECD Steering Group on Corporate Governance Report.

Pathan, Shams. (2009) "Strong boards, CEO power and bank risk-taking." Journal of Banking \& Finance 33(7), 1340-1350.

Pettway, Richard H., and Joseph F. Sinkey, Jr. (1980) "Establishing on-site bank examination priorities: an early-warning system using accounting and market information." The Journal of Finance 35(1), 137-150.

Roy, Andrew D. (1952) “Safety First and the Holding of Assets.” Econometrica 20(3), 431-449.

Saunders, Anthony, Elizabeth Strock, and Nickolaos G. Travlos. (1990) “Ownership structure, deregulation, and bank risk taking." The Journal of Finance 45(2), 643-654. 
Schaeck, Klaus. (2008) "Bank liability structure, FDIC loss, and time to failure: A quantile regression approach.” Journal of Financial Services Research 33(3), 163-179.

Schaeck, Klaus, Martin Cihák, and Simon Wolfe. (2009) “Are more competitive banking systems more stable?” Journal of Money, Credit, and Banking 41(4), 711-734.

Squam Lake Working Group on Financial Regulation. (2010) "Regulation of executive compensation in financial services.” Manuscript.

Sullivan, Richard J., and Kenneth R. Spong. (2007) "Manager wealth concentration, ownership structure, and risk in commercial banks.” Journal of Financial Intermediation 16(2), 229248.

Thomson, James B. (1991) "Predicting bank failures in the 1980s." Economic Review Federal Reserve Bank of Cleveland Q1/1991, 9-20.

Thomson, James B. (1992) "Modeling the bank regulator's closure option: A two-step logit regression approach.” Journal of Financial Services Research 6(5), 5-23.

UBS. (2008) “Shareholder Report on UBS’s Write-Downs”, Manuscript Zurich, Switzerland.

Whalen, Gary, and James B. Thomson. (1988) "Using financial data to identify changes in bank condition." Economic Review Federal Reserve Bank of Cleveland 24(2), 17-26.

White, Halbert. (1980) “A heteroskedasticity-consistent covariance matrix estimator and a direct test for heteroscedasticity." Econometrica 48(4), 817-830. 
1 An exception is Berger and Bouwman (2013), which controls for institutional block ownership, bank holding company membership, and foreign ownership in models of bank survival and market share. However, the paper does not focus on these variables, nor does it include the ownership of directors and different types of bank employees, which are the key corporate governance variables of interest here.

2 Bruno M. Iksil was the trader of a synthetic credit risk portfolio. His direct supervisors with whom he ran the portfolio were Javier Martin-Artajo (Head of Credit Trading) and Achilles Macris (Senior Executive VP of Trading Operations in London). Both fall under our description of "lower-level management."

3 Another corporate governance-related body of research focuses on compensation structures in banks with special regard to risk. Among the most recent works on bank management compensation and risk taking behavior are Kirkpatrick (2009), Bebchuk and Spamann (2010), Fahlenbrach and Stulz (2011), Bhattacharyya and Purnanandam (2012), and DeYoung, Peng, and Yan (2013).

4 As noted above, Berger and Bouwman (2013) include institutional block ownership, bank holding company membership, and foreign ownership as control variables in models of bank survival and market share. They do not find strong, consistent results for any of these variables.

5 As obtained through the FDIC website: http://www.fdic.gov/bank/individual/failed/banklist.html.

6 Note that our dataset contains information about all banks with a 'public' company status of the SEC. SEC regulations call for share registration prospectuses and other filing documentation made publicly available through EDGAR whenever a company meets the criteria for being 'public.' This includes having public shares registered on a stock exchange, or, for unlisted banks, having more than 10million in assets and at least 500 security holders (following Rule $12 \mathrm{~g}-1$ of the Amendment to the 1934 Securities and Exchange Act.) Following Regulation S-K, public companies have to disclose all 'material information,' of which ownership and compensation is a part. Since reporting guidelines are the same for every 'public' bank, we obtain homogenous information on bank governance, not driven by disclosure discretion.

7 Note that we cannot use Cap IQ data alone because it does not contain the total fraction of shares held by managers and directors in their respective banks. We do not use the more commonly employed Compustat Execucomp database because it does not contain necessary information on compensation and ownership of lower-level management, and because it has a lower matching rate with Mergent than Cap IQ.

8 Our observation period for bank failures only contains 15 quarters (2007:Q1-2010:Q3). However, as some of our explanatory variables date back to 2006:Q1, we obtain 19 quarters of observation period. Given the number of banks ( 85 failed and 256 non-failed banks), we would hypothetically obtain a maximum possible number of 6,479 bankquarter observations. However, due to data limitations we lose some observations and end up with 6,152 bankquarter observations.

9 Merged or acquired banks are treated as if the banks involved had been merged at the beginning of the observation period by consolidating the banks' balance sheets. As a robustness check, we exclude all merged and acquired banks from our data set. Results remain unchanged.

10 We also exclude all savings institutions with a thrift charter obtained through the Office of Thrift Supervision. This also includes all failed thrifts and thrift SIFIs (such as Washington Mutual and IndyMac). We do so for reasons of comparability and to obtain a homogenous sample of commercial banks only.

11 The subprime exposure cannot be calculated on single bank-entity level, as HMDA data are only reported for census tracts/MSAs.

12 The FDIC publishes Material Loss Reports for all bank failures which result in a "material loss" to the FDIC insurance fund. On January 1st 2010, the "material loss" threshold was raised from $\$ 25$ million to $\$ 200$ million.

13 Interestingly, we also only find 4 banks with designated "Vice President of Risk" positions and 2 banks with "Head of Risk" positions, supporting our assumption regarding the Chief Risk Officer.

14 The group of Vice Presidents is comprised of Executive Vice Presidents (60.4\%), Senior Vice Presidents (27.6\%), Vice Presidents (11.8\%), and Assistant Vice Presidents $(0.2 \%)$. Most frequently mentioned position is VP of Lending.

15 Most frequently mentioned positions are Head of Corporate Banking and Head of Retail Banking.

16 We classify each mortgage granted to a borrower with income less than $50 \%$ of the median income in the respective census tract or MSA as "subprime." Although we acknowledge that some of these borrowers might be classified as "prime" borrowers in some cases, we believe it to be a fair assumption that these borrowers can be deemed as rather high-risk, and hence we group them as "subprime."

17 We use total deposits in calculating the HHI because it is the only bank output for which location is available.

18 We use the state economic variables from the states in which the banks have deposits. For banks with branches in multiple states, we calculate the weighted exposure to each state through the FDIC Summary of Deposits data, as previously used for the HHI calculation, to obtain a weighted exposure to the state economic variables. 
19 Note that some banks stop reporting accounting data when failure approaches. This results in a slightly lower number of failed banks included in the regressions when using exogenous variables one year prior to failure.

20 Such bias could occur if, for example, during the financial crisis, managers of failing banks knew that they were likely to fail and sold their stock. This would give a bias toward finding that banks with higher managerial shares were less likely to fail. In our specifications, we assume that none of the managers anticipated a high probability of failure as of the end of 2006, consistent with Fahlenbrach and Stulz (2011) who show that bank CEOs did not sell stock in anticipation of the crisis. However, very recent studies show that some managers might have already adjusted their holdings as early as mid-2006 when housing prices started to decline (Cziraki, 2014). We therefore rerun all regressions with the exogenous variables measured in the fixed periods of 2006:Q1, 2006:Q2 and 2006:Q3. The results are the same.

21 In a robustness test shown in the Online Appendix, we also try the total number of shares held as standardization measure. Results do not change.

22 In-depth overviews of the topic of executive compensation, along with examples, literature reviews, explanations and with regard to the recent financial crisis are given by Bebchuk and Spamann (2010) and Mehran, Morrison and Shapiro (2011).

23 As a robustness check, we replace the multibank holding company (BHC) dummy with a dummy indicating whether the bank is part of any BHC structure, either single-bank or multibank. The results remain unchanged.

24 As a robustness test, we also standardize the numbers of outside directors, chief officers, and lower-level managers by the asset size of the bank. The results remain unchanged.

$25 \mathrm{We}$ do not include the off-balance sheet derivative exposure of the banks in our analyses as no failed bank in our data sample has exposure to these.

26 According to the literature, higher market power may result in either a higher or a lower probability of bank failure. In the traditional "competition-fragility" view, higher market power increases profit margins and results in greater franchise value with banks reducing risk taking to protect this value (e.g., Marcus, 1984; Keeley, 1990; Demsetz, Saidenberg, and Strahan, 1996; Hellmann, Murdock, and Stiglitz, 2000; Carletti and Hartmann, 2003; Jiménez, Lopez, and Saurina, 2013). Thus, a higher HHI may result in a lower probability of failure. In contrast, in the "competition-stability" view, more market power in the loan market may result in higher bank risk and a higher probability of failure as the higher interest rates charged to loan customers make it harder to repay loans and exacerbate moral hazard and adverse selection problems (e.g., Boyd and De Nicoló, 2005; Boyd, De Nicoló, and Jalal, 2006; De Nicoló and Loukoianova, 2007; Schaeck, Cihák, and Wolfe, 2009). Berger, Klapper, and Turk-Ariss (2009) find that the two views do not necessarily yield opposing predictions and find evidence supporting both. Martinez-Miera and Repullo (2010) predict a potential non-monotonic U-shape relationship between market power and risk-taking.

$27 \mathrm{We}$ also repeat all tests clustering banks at the holding company level to eliminate that results are driven by spurious significances due to repeated observations. All findings remain the same.

28 We do not include subprime loan market exposure in the first stage and are therefore able to estimate the first stage based on a sample of about 4,000 banks.

29 Average bank failure probability in our sample is $1.38 \%$.

30 Limited liability of shareholders might be sufficient for this argument, but Merton (1977) extends it to banks and the bank-specific deposit insurance.

31 We acknowledge that there are exceptions, such as Nick Leeson of Barings, Jérôme Kerviel of Société Générale, and Kweku M. Adoboli of UBS, who became known to the public. However, all of these now infamous cases were based on fraudulent risk taking, as opposed to risk taking within the allowed boundaries. The news on these tail events also supports the notion that lower-level employees may have a tremendous impact on bank risk. 


\section{Table $1 \quad$ Description of Variables}

The table shows descriptions of virtually all variables used in the analyses together with their units of measurement. All financial variables are measured in real terms with 2005 as the base year using the consumer price index (CPI).

\begin{tabular}{|c|c|c|}
\hline Variable Name & Unit & Description \\
\hline \multicolumn{3}{|c|}{ Corporate Governance Variables } \\
\hline Outside Directors & $\%$ & $\begin{array}{l}\text { Members of the board of directors who do not perform any other function than being } \\
\text { directors of the bank. }\end{array}$ \\
\hline CEO & $\%$ & The Chief Executive Officer or co-Chief Executive Officer of the bank. \\
\hline Other higher-level Mgmt. & $\%$ & $\begin{array}{l}\text { Higher-level management employed by the bank excluding the CEO. This includes all } \\
\text { managers with a "chief officer" position as shown in detail in Table } 3 \text {. }\end{array}$ \\
\hline Lower-level Mgmt. & $\%$ & $\begin{array}{l}\text { Lower-level management employed by the bank excluding the CEO and higher-level } \\
\text { management. Positions are shown in detail in Table } 3 \text {. }\end{array}$ \\
\hline \multicolumn{3}{|l|}{ Ownership Variables } \\
\hline $\begin{array}{l}\text { Share Ownership / Total } \\
\text { Shares }\end{array}$ & $\%$ & $\begin{array}{l}\text { Ratio of the number of shares held derived on the group level (i.e., CEO, lower-level and } \\
\text { higher-level management and outside directors) to the bank's total number of shares } \\
\text { outstanding. }\end{array}$ \\
\hline $\begin{array}{l}\text { Option Holdings / Total } \\
\text { Assets }\end{array}$ & $\%$ & $\begin{array}{l}\text { Ratio of the average value of option holdings derived on the individual level to the bank's } \\
\text { total asset value. }\end{array}$ \\
\hline \multicolumn{3}{|l|}{ Compensation Variables } \\
\hline $\begin{array}{l}\text { Stock \& Option Awards / } \\
\text { Total Compensation }\end{array}$ & $\%$ & $\begin{array}{l}\text { Ratio of the annual stock awards and option awards to total compensation derived on the } \\
\text { individual level. In regressions lagged by one year to account for the year when } \\
\text { performance is measured. Total compensation includes the annual salary, bonus, fees } \\
\text { (such as director fees), option awards, stock awards, long-term incentive compensation } \\
\text { (such as pension plans and long-term incentive compensation) and all other annual } \\
\text { compensation. }\end{array}$ \\
\hline $\begin{array}{l}\text { Bonus / Total } \\
\text { Compensation }\end{array}$ & $\%$ & $\begin{array}{l}\text { Ratio of the annual bonus payment to total compensation derived on the individual level. } \\
\text { In regressions lagged by one year to account for the year when performance is measured. } \\
\text { Total compensation includes the annual salary, bonus, fees (such as director fees), option } \\
\text { awards, stock awards, long-term incentive compensation (such as pension plans and long- } \\
\text { term incentive compensation) and all other annual compensation. }\end{array}$ \\
\hline TARP & Dummy & Dummy variable indicating whether the bank received and holds TARP funds. \\
\hline Public Bank & Dummy & $\begin{array}{l}\text { Dummy variable indicating whether the bank has publicly traded securities. Subsidiaries } \\
\text { of publicly traded bank holding companies are considered to be public. }\end{array}$ \\
\hline $\begin{array}{l}\text { Multibank Holding } \\
\text { Company }\end{array}$ & Dummy & $\begin{array}{l}\text { Dummy variable indicating whether the bank is a subsidiary of a bank holding company } \\
\text { with more than } 1 \text { bank. }\end{array}$ \\
\hline \multicolumn{3}{|l|}{ Management Variables } \\
\hline Outside Directors/Board & Ratio & $\begin{array}{l}\text { Ratio of the number of the members of the board of directors who do not perform any } \\
\text { other function than being board directors of the bank to the board size (the number of } \\
\text { members of the board of directors). }\end{array}$ \\
\hline $\begin{array}{l}\text { Higher-level } \\
\text { Mgmt./Board }\end{array}$ & Ratio & $\begin{array}{l}\text { Ratio of the number of higher-level management employed with the bank (members of the } \\
\text { executive board) to the board size (the number of members of the board of directors). }\end{array}$ \\
\hline Lower-level & Ratio & Ratio of the number of lower-level management employed with the bank excluding the \\
\hline Mgmt./Board & & $\begin{array}{l}\text { CEO and higher-level management to the board size (the number of members of the board } \\
\text { of directors). }\end{array}$ \\
\hline $\log ($ Board Size $)$ & Integer & Natural logarithm of the number of members of the board of directors. \\
\hline Chairman is CEO & Dummy & $\begin{array}{l}\text { Dummy variable indicating whether the Chairman of the Board of Directors is also the } \\
\text { Chief Executive Officer (CEO) of the same bank. }\end{array}$ \\
\hline \multicolumn{3}{|l|}{ Accounting Variables } \\
\hline $\log$ (Assets) & $\begin{array}{c}\log \\
(\$ \text { Thd. })\end{array}$ & Natural logarithm of total assets in $\$$ thousand as reported on the balance sheet. \\
\hline Capital Ratio & $\%$ & Ratio of equity capital to total assets as reported on the balance sheet. \\
\hline $\begin{array}{l}\text { Total Loans excl. } \\
\text { C\&D/Assets }\end{array}$ & $\%$ & $\begin{array}{l}\text { Ratio of the total volume of all outstanding loans excluding construction and development } \\
\text { (C\&D) loans to total assets as reported on the balance sheet. }\end{array}$ \\
\hline $\begin{array}{l}\text { Construction \& } \\
\text { Development }(C \& D)\end{array}$ & $\%$ & $\begin{array}{l}\text { Ratio of the total volume of all construction \& development (C\&D) loans to total assets as } \\
\text { reported on the balance sheet. }\end{array}$ \\
\hline
\end{tabular}




\begin{tabular}{|c|c|c|}
\hline \multicolumn{3}{|l|}{ Loans/Assets } \\
\hline Loan Concentration & Index & $\begin{array}{l}\text { Herfindahl-Hirschman Index (HHI) of bank level loan portfolio concentration. It is } \\
\text { calculated by summing the squared percentage of each loan category to the bank's total } \\
\text { loans, and ranges from } 0 \text { to } 1 \text {. }\end{array}$ \\
\hline ST Deposits/Assets & $\%$ & $\begin{array}{l}\text { Ratio of short-term deposits (transaction and demand deposits) to total assets as reported } \\
\text { on the balance sheet. }\end{array}$ \\
\hline Brokered Deposits/Assets & $\%$ & Ratio of brokered deposits to total assets as reported on the balance sheet. \\
\hline Return on Assets & $\%$ & $\begin{array}{l}\text { Ratio of net income as reported on the profit and loss account to total assets as reported on } \\
\text { the balance sheet. }\end{array}$ \\
\hline $\begin{array}{l}\text { Non-perform. } \\
\text { Loans/Assets }\end{array}$ & $\%$ & $\begin{array}{l}\text { Ratio of all non-performing loans (all loans } 90 \text { days past due plus all loans charged-off) to } \\
\text { total assets as reported on the balance sheet. }\end{array}$ \\
\hline Loan Growth & $\%$ & $\begin{array}{l}\text { Quarterly growth in the total volume of deflated outstanding loans as reported on the } \\
\text { balance sheet. }\end{array}$ \\
\hline MBS/Assets & $\%$ & Ratio of mortgage-backed securities (MBS) to total assets as reported on the balance sheet. \\
\hline Unused & $\%$ & Ratio of all unused loan commitments as reported in the bank's off-balance sheet statement \\
\hline Commitm./Assets & & to total assets as reported on the balance sheet. \\
\hline \multicolumn{3}{|c|}{ Market Competition Variables } \\
\hline Local Market Power & Index & $\begin{array}{l}\text { Herfindahl-Hirschman Index (HHI) of market concentration based on the bank's weighted } \\
\text { deposits in the Metropolitan Statistical Areas (MSA) or rural counties in which it operates, } \\
\text { and ranges from } 0 \text { to } 1 \text {. }\end{array}$ \\
\hline (Local Market Power) $^{2}$ & Index ${ }^{2}$ & The squared value of "Local Market Power." \\
\hline $\begin{array}{l}\text { Competitors' Subprime } \\
\text { Exposure }\end{array}$ & $\%$ & $\begin{array}{l}\text { The ratio of originated subprime loans to total originated loans in the bank's local markets. } \\
\text { It is used in the analyses as the annual average from } 2004-2008 \text { in the respective bank's } \\
\text { census tract weighted by the bank's deposits in each census tract employing data of the } \\
\text { Home Mortgage Disclosure Act (HMDA). }\end{array}$ \\
\hline \multicolumn{3}{|c|}{ State-Level Economic Variables } \\
\hline House Price Inflation & $\%$ & $\begin{array}{l}\text { Quarterly inflation rate of the seasonally-adjusted Federal Housing Finance Agency's } \\
\text { (FHFA) house price index in the bank's state. }\end{array}$ \\
\hline$\%$-Change in GDP & $\%$ & $\begin{array}{l}\text { Quarterly percentage change in the Gross Domestic Product (GDP) in the bank's state } \\
\text { proxied by the quarterly state personal income provided by the Bureau of Economic } \\
\text { Analysis. }\end{array}$ \\
\hline \multicolumn{3}{|c|}{ Primary Federal Regulator Variables } \\
\hline OCC & Dummy & $\begin{array}{l}\text { Dummy variable indicating whether the bank has a national bank charter, so the bank's } \\
\text { primary federal regulator is the OCC. }\end{array}$ \\
\hline FED & Dummy & $\begin{array}{l}\text { Dummy variable indicating whether the bank is a state-chartered Federal Reserve member, } \\
\text { so the Federal Reserve is the bank's primary federal regulator. }\end{array}$ \\
\hline
\end{tabular}




\section{Table $2 \quad$ Bank failure characteristics and loss to FDIC fund}

The table shows the characteristics of the US commercial bank failures included in the study. In Panel A, the number of failed banks and the corresponding total loss to the FDIC insurance fund in \$ million in current year dollars (estimated through the FDIC at the time of failure) in the parentheses below is provided by failure reason. The respective reason is identified via official press releases and loss reports of regulatory agencies, newspaper articles, and wire news. "General crisis related" means that it is mentioned that the financial crisis was the main reason for the failure. Panel B shows the percentage of banks with bad risk management, to which a cease-and-desist order had been issued before failure by the respective regulatory agency, and where the failure was surprising. "Bad Risk Management" is used as stated by the FDIC after having taken the bank into conservatorship and examining the failure in the Material Loss Report (MLR). For the identification of a cease-and-desist order we employ the press releases of the "FDIC Enforcement Decisions and Orders" available online at the FDIC website. A bank failure is defined as "surprising" when it was not anticipated by bank regulators and/or institutional rating experts. Whether or not a bank failure was "surprising" is taken from two different sources. First, the MLRs in which the FDIC states whether or not it could have anticipated the failure at prior examinations. The second source is LACE bank ratings during the quarters leading up to the failure. These derive from LACE Financial, an independent (often uncompensated) boutique credit-ratings firm specialized in rating banks and other financial services firms. It was founded in 1984 and acquired by Kroll BondRatings in August 2010. If the assigned LACE rating is not F (worst) in the quarter before failure, the failure is also deemed "surprising." All data except the LACE ratings are provided on the authors' websites.

\begin{tabular}{lcccccccc} 
Panel A: Failure Reasons & $2009: \mathrm{Q} 1$ & $2009: \mathrm{Q} 2$ & $2009: \mathrm{Q} 3$ & $2009: \mathrm{Q} 4$ & $2010: \mathrm{Q} 1$ & $2010: \mathrm{Q} 2$ & $2010: \mathrm{Q} 3$ & Total \\
\hline \multirow{2}{*}{ General Crisis Related } & 0 & 0 & 10 & 5 & 4 & 6 & 7 & 32 \\
& $(\$ 0)$ & $(\$ 0)$ & $(\$ 188)$ & $(\$ 64)$ & $(\$ 84)$ & $(\$ 106)$ & $(\$ 57)$ & $(\$ 499)$ \\
Loan Losses Only & 7 & 5 & 9 & 2 & 7 & 6 & 5 & 41 \\
\multirow{2}{*}{ Liquidity Problems and Loan Losses } & $(\$ 135)$ & $(\$ 115)$ & $(\$ 329)$ & $(\$ 729)$ & $(\$ 270)$ & $(\$ 162)$ & $(\$ 103)$ & $(\$ 1,842)$ \\
\multirow{2}{*}{ Other } & $(\$ 146)$ & $(\$ 124)$ & $(\$ 64)$ & $(\$ 96)$ & $(\$ 250)$ & $(\$ 84)$ & $(\$ 0)$ & $(\$ 763)$ \\
& 0 & 0 & 0 & 1 & 0 & 0 & 0 & 1 \\
\multirow{2}{*}{ Total } & $(\$ 0)$ & $(\$ 0)$ & $(\$ 0)$ & $(\$ 469)$ & $(\$ 0)$ & $(\$ 0)$ & $(\$ 0)$ & $(\$ 469)$ \\
\hline
\end{tabular}

\begin{tabular}{lcccccccc}
\cline { 2 - 8 } Panel B: Failure Surroundings & $2009: \mathrm{Q} 1$ & $2009: \mathrm{Q} 2$ & $2009: \mathrm{Q} 3$ & $2009: \mathrm{Q} 4$ & $2010: \mathrm{Q} 1$ & $2010: \mathrm{Q} 2$ & $2010: \mathrm{Q} 3$ & Total \\
\hline Bad Risk Management & $44.44 \%$ & $57.14 \%$ & $9.52 \%$ & $20.00 \%$ & $23.08 \%$ & $7.69 \%$ & $8.33 \%$ & $20.00 \%$ \\
Cease-and-Desist Order & $22.22 \%$ & $42.86 \%$ & $47.62 \%$ & $30.00 \%$ & $38.46 \%$ & $30.77 \%$ & $8.33 \%$ & $32.94 \%$ \\
Failure Surprising & $11.11 \%$ & $28.57 \%$ & $4.76 \%$ & $0.00 \%$ & $7.69 \%$ & $7.69 \%$ & $0.00 \%$ & $7.06 \%$ \\
\hline
\end{tabular}




\section{Table $3 \quad$ Corporate governance variables}

The table shows classifications and descriptive statistics of corporate governance variables. The table is based on the subset of 6,152 observations for the 341 banks for which we have corporate governance data. All variables are defined in Table 1. Panel A shows the classification and percentage of job positions within the respective group of our main categories board of directors - outside, CEO, other higher-level management, and lower-level management. Note that the "Percentages in Group" in the right column sum up to $100 \%$. Each group ("Classification" in middle column) is collectively comprised of the job functions as shown in the left column. Panel B provides descriptive statistics of ownership and compensation where each variable is provided as the average per person with the exception of Percentage Share Ownership which is shown as the average of the aggregate of each group in each bank. Panel C displays the Percentage Share Ownership as the average of each group in each bank and the variable Option Holdings / Total Assets (\$-Thd.) as the average of each person in each group, both over asset deciles including all our 341 banks with available corporate governance data. Panel D shows average values and standard deviations in the parentheses below by failed and non-failed banks. The statistical difference of the respective value between failure and no failure banks is derived via a t-test for unpaired data with unequal variance and indicated by * $=10 \%$ level, $* *=5 \%$ level and $* * *=1 \%$ level.

\section{Panel A: Job Classifications}

\begin{tabular}{lcc}
\hline \multicolumn{1}{c}{ Function Name } & Classification & Percentage in Group \\
\hline Chairman/Vice-Chairman of the Board & Board of Directors - Outside & $20.7 \%$ \\
Member of the Board of Directors & Board of Directors - Outside & $79.3 \%$ \\
Chief Executive Officer/Co-Chief Executive Officer & CEO & $79.1 \%$ \\
President/Co-President & CEO & $20.9 \%$ \\
Chief Financial Officer & Other higher-level Management & $46.4 \%$ \\
Chief Lending Officer & Other higher-level Management & $19.9 \%$ \\
Chief Operating Officer & Other higher-level Management & $15.9 \%$ \\
Chief Risk Officer & Other higher-level Management & $4.4 \%$ \\
Other Chief Officers & Other higher-level Management & $13.4 \%$ \\
Vice Presidents & Lower-level Management & $81.5 \%$ \\
Department Heads („Head of“) & Lower-level Management & $10.4 \%$ \\
Corporate Secretaries & Lower-level Management & $7.0 \%$ \\
Treasurers & Lower-level Management & $0.9 \%$ \\
Other Lower-Level Managers & Lower-level Management & $0.2 \%$ \\
\hline
\end{tabular}




\begin{tabular}{|c|c|c|c|c|}
\hline $\begin{array}{l}\text { Panel B: Ownership and } \\
\text { Compensation Variables }\end{array}$ & $\begin{array}{l}\text { Outside } \\
\text { Directors }\end{array}$ & CEO & $\begin{array}{c}\text { Other higher- } \\
\text { level } \\
\text { Management }\end{array}$ & $\begin{array}{l}\text { Lower-level } \\
\text { Management }\end{array}$ \\
\hline \multicolumn{5}{|l|}{ Number of Individuals per Bank } \\
\hline Mergent database & $\begin{array}{l}12.190 \\
(6.041)\end{array}$ & $\begin{array}{l}1.145 \\
(0.429)\end{array}$ & $\begin{array}{l}4.510 \\
(3.011)\end{array}$ & $\begin{array}{l}21.012 \\
(10.924)\end{array}$ \\
\hline Capital IQ database & $\begin{array}{l}13.677 \\
(8.437)\end{array}$ & $\begin{array}{c}1.391 \\
(0.566)\end{array}$ & $\begin{array}{c}3.758 \\
(1.478)\end{array}$ & $\begin{array}{c}19.892 \\
(13.131)\end{array}$ \\
\hline \multicolumn{5}{|l|}{ Ownership } \\
\hline Percentage Share Ownership & $\begin{array}{c}9.547 \% \\
(13.773 \%)\end{array}$ & $\begin{array}{l}1.751 \% \\
(3.783 \%)\end{array}$ & $\begin{array}{c}0.962 \% \\
(2.838 \%)\end{array}$ & $\begin{array}{c}5.711 \% \\
(16.816 \%)\end{array}$ \\
\hline Total Option Value & $\begin{array}{c}3,363 \\
(96,751)\end{array}$ & $\begin{array}{c}807,050 \\
(4,285,013)\end{array}$ & $\begin{array}{c}203,252 \\
(1,404,960)\end{array}$ & $\begin{array}{c}184,253 \\
(1,347,610)\end{array}$ \\
\hline \multicolumn{5}{|l|}{ Variable Compensation } \\
\hline Salary & $\begin{array}{c}36,547 \\
(41,465)\end{array}$ & $\begin{array}{c}377,254 \\
(290,080)\end{array}$ & $\begin{array}{c}202,843 \\
(141,727)\end{array}$ & $\begin{array}{c}143,855 \\
(166,538)\end{array}$ \\
\hline Bonus & $\begin{array}{c}142 \\
(5,712)\end{array}$ & $\begin{array}{c}71,522 \\
(340,952)\end{array}$ & $\begin{array}{c}28,856 \\
(127,885)\end{array}$ & $\begin{array}{c}25,514 \\
(214,894)\end{array}$ \\
\hline Option Awards & $\begin{array}{c}3,521 \\
(25,531)\end{array}$ & $\begin{array}{c}173,995 \\
(758,732)\end{array}$ & $\begin{array}{c}54,615 \\
(271,383)\end{array}$ & $\begin{array}{c}49,588 \\
(267,571)\end{array}$ \\
\hline Stock Awards & $\begin{array}{c}11,745 \\
(84,587)\end{array}$ & $\begin{array}{c}965,254 \\
(4,095,119)\end{array}$ & $\begin{array}{c}368,475 \\
(2,103,710)\end{array}$ & $\begin{array}{c}346,576 \\
(2,481,312)\end{array}$ \\
\hline Long-term Incentives & $\begin{array}{c}3,993 \\
(50,543)\end{array}$ & $\begin{array}{c}361,253 \\
(932,265)\end{array}$ & $\begin{array}{c}145,351 \\
(635,696)\end{array}$ & $\begin{array}{c}140,889 \\
(899,425)\end{array}$ \\
\hline Total Compensation & $\begin{array}{c}59,639 \\
(174,950) \\
\end{array}$ & $\begin{array}{r}1,951,083 \\
(5,681,560) \\
\end{array}$ & $\begin{array}{c}801,167 \\
(2,814,202) \\
\end{array}$ & $\begin{array}{c}708,527 \\
(3,103,155) \\
\end{array}$ \\
\hline $\begin{array}{l}\text { Panel C: Ownership by Bank Asset } \\
\text { Deciles }\end{array}$ & $\begin{array}{c}\text { Outside } \\
\text { Directors }\end{array}$ & $\mathrm{CEO}$ & $\begin{array}{l}\text { Higher-level } \\
\text { Management }\end{array}$ & $\begin{array}{r}\text { Lower-level } \\
\text { Management }\end{array}$ \\
\hline \multicolumn{5}{|l|}{ Percentage Share Ownership } \\
\hline Smallest $10 \%$ Banks & $8.105 \%$ & $3.029 \%$ & $1.187 \%$ & $11.823 \%$ \\
\hline $10 \%<$ Banks $\leq 20 \%$ & $17.071 \%$ & $3.012 \%$ & $1.144 \%$ & $7.406 \%$ \\
\hline $20 \%<$ Banks $\leq 30 \%$ & $12.596 \%$ & $1.955 \%$ & $0.899 \%$ & $5.856 \%$ \\
\hline $30 \%<$ Banks $\leq 40 \%$ & $9.704 \%$ & $1.301 \%$ & $0.714 \%$ & $5.405 \%$ \\
\hline $40 \%<$ Banks $\leq 50 \%$ & $12.169 \%$ & $1.613 \%$ & $0.940 \%$ & $6.989 \%$ \\
\hline $50 \%<$ Banks $\leq 60 \%$ & $10.788 \%$ & $1.823 \%$ & $0.817 \%$ & $5.275 \%$ \\
\hline $60 \%<$ Banks $\leq 70 \%$ & $9.996 \%$ & $1.341 \%$ & $0.853 \%$ & $4.763 \%$ \\
\hline $70 \%<$ Banks $\leq 80 \%$ & $5.801 \%$ & $2.016 \%$ & $0.905 \%$ & $2.246 \%$ \\
\hline $80 \%<$ Banks $\leq 90 \%$ & $5.253 \%$ & $0.857 \%$ & $1.780 \%$ & $5.412 \%$ \\
\hline Largest $10 \%$ Banks & $3.525 \%$ & $0.389 \%$ & $0.225 \%$ & $1.513 \%$ \\
\hline \multicolumn{5}{|c|}{ Option Holdings / Total Assets (\$-Thd.) } \\
\hline Smallest $10 \%$ Banks & $0.000 \%$ & $5.738 \%$ & $3.511 \%$ & $1.658 \%$ \\
\hline $10 \%<$ Banks $\leq 20 \%$ & $0.010 \%$ & $38.536 \%$ & $20.547 \%$ & $1.501 \%$ \\
\hline $20 \%<$ Banks $\leq 30 \%$ & $0.000 \%$ & $6.007 \%$ & $1.929 \%$ & $0.126 \%$ \\
\hline $30 \%<$ Banks $\leq 40 \%$ & $0.065 \%$ & $15.678 \%$ & $3.157 \%$ & $1.261 \%$ \\
\hline $40 \%<$ Banks $\leq 50 \%$ & $0.569 \%$ & $14.309 \%$ & $4.848 \%$ & $4.940 \%$ \\
\hline $50 \%<$ Banks $\leq 60 \%$ & $0.320 \%$ & $19.644 \%$ & $6.028 \%$ & $8.785 \%$ \\
\hline $60 \%<$ Banks $\leq 70 \%$ & $0.119 \%$ & $17.079 \%$ & $3.618 \%$ & $3.680 \%$ \\
\hline $70 \%<$ Banks $\leq 80 \%$ & $0.033 \%$ & $11.317 \%$ & $4.017 \%$ & $1.795 \%$ \\
\hline $80 \%<$ Banks $\leq 90 \%$ & $0.284 \%$ & $11.410 \%$ & $3.759 \%$ & $2.857 \%$ \\
\hline Largest $10 \%$ Banks & $0.014 \%$ & $13.077 \%$ & $2.470 \%$ & $1.702 \%$ \\
\hline
\end{tabular}




\begin{tabular}{|c|c|c|c|c|}
\hline \multirow{2}{*}{\multicolumn{2}{|c|}{$\begin{array}{l}\text { Panel D: Ownership and Compensation } \\
\text { Variables by Bank Failure }\end{array}$}} & \\
\hline & & No Failure & Failure & Difference \\
\hline \multicolumn{5}{|c|}{ Corporate Governance Variables } \\
\hline & Ownership Variables & & & \\
\hline \multirow{4}{*}{$\begin{array}{l}\text { Share Ownership / } \\
\text { Total Shares }\end{array}$} & Outside Directors & $\begin{array}{l}0.076 \\
(0.117)\end{array}$ & $\begin{array}{l}0.166 \\
(0.181)\end{array}$ & $0.090 * * *$ \\
\hline & $\mathrm{CEO}$ & $\begin{array}{l}0.014 \\
(0.037)\end{array}$ & $\begin{array}{l}0.029 \\
(0.037)\end{array}$ & $0.015 * * *$ \\
\hline & Other higher-level Mgmt. & $\begin{array}{l}0.005 \\
(0.010)\end{array}$ & $\begin{array}{l}0.026 \\
(0.055)\end{array}$ & $0.021 * * *$ \\
\hline & Lower-level Mgmt. & $\begin{array}{l}0.029 \\
(0.083)\end{array}$ & $\begin{array}{l}0.161 \\
(0.304)\end{array}$ & $0.132 * * *$ \\
\hline \multirow{9}{*}{$\begin{array}{c}\text { Option Holdings / } \\
\text { Total Assets (\$- } \\
\text { Thd.) }\end{array}$} & Outside Directors & $\begin{array}{c}0.002 \\
(0.018)\end{array}$ & $\begin{array}{l}0.001 \\
(0.006)\end{array}$ & $-0.001 * * *$ \\
\hline & CEO & $\begin{array}{l}0.144 \\
(0.693)\end{array}$ & $\begin{array}{l}0.186 \\
(0.653)\end{array}$ & $0.041 * *$ \\
\hline & Other higher-level Mgmt. & $\begin{array}{l}0.054 \\
(0.335)\end{array}$ & $\begin{array}{c}0.053 \\
(0.209)\end{array}$ & -0.002 \\
\hline & Lower-level Mgmt. & $\begin{array}{l}0.027 \\
(0.152)\end{array}$ & $\begin{array}{c}0.034 \\
(0.139)\end{array}$ & 0.007 \\
\hline & Other Ownership Variables & & & \\
\hline & TARP & $\begin{array}{c}0.379 \\
(0.485)\end{array}$ & $\begin{array}{l}0.050 \\
(0.219)\end{array}$ & $-0.328 * * *$ \\
\hline & Public Bank & $\begin{array}{c}0.438 \\
(0.496)\end{array}$ & $\begin{array}{l}0.699 \\
(0.459)\end{array}$ & $0.261 * * *$ \\
\hline & Multibank Holding Company & $\begin{array}{l}0.117 \\
(0.322)\end{array}$ & $\begin{array}{l}0.180 \\
(0.384)\end{array}$ & $0.063 * * *$ \\
\hline & Variable Compensation Variables & & & \\
\hline \multirow{4}{*}{$\begin{array}{l}\text { Stock \& Option } \\
\text { Awards / Total } \\
\text { Compensation }\end{array}$} & Outside Directors & $\begin{array}{l}0.088 \\
(0.160)\end{array}$ & $\begin{array}{l}0.071 \\
(0.152)\end{array}$ & $-0.017 * * *$ \\
\hline & CEO & $\begin{array}{l}0.125 \\
(0.215)\end{array}$ & $\begin{array}{l}0.075 \\
(0.138)\end{array}$ & $-0.050 * * *$ \\
\hline & Other higher-level Mgmt. & $\begin{array}{l}0.108 \\
(0.195)\end{array}$ & $\begin{array}{l}0.057 \\
(0.100)\end{array}$ & $-0.051 * * *$ \\
\hline & Lower-level Mgmt. & $\begin{array}{l}0.078 \\
(0.166)\end{array}$ & $\begin{array}{l}0.061 \\
(0.137)\end{array}$ & $-0.017 * * *$ \\
\hline \multirow{9}{*}{$\begin{array}{l}\text { Bonus / Total } \\
\text { Compensation }\end{array}$} & CEO & $\begin{array}{c}0.042 \\
(0.089)\end{array}$ & $\begin{array}{l}0.039 \\
(0.099)\end{array}$ & -0.003 \\
\hline & Other higher-level Mgmt. & $\begin{array}{l}0.041 \\
(0.077)\end{array}$ & $\begin{array}{l}0.032 \\
(0.075)\end{array}$ & $-0.009 * * *$ \\
\hline & Lower-level Mgmt. & $\begin{array}{l}0.028 \\
(0.070)\end{array}$ & $\begin{array}{l}0.024 \\
(0.074)\end{array}$ & $-0.004 *$ \\
\hline & Management Variables & & & \\
\hline & Outside Directors/Board & $\begin{array}{c}0.886 \\
(0.093)\end{array}$ & $\begin{array}{c}0.882 \\
(0.122)\end{array}$ & -0.004 \\
\hline & Higher-level Mgmt./Board & $\begin{array}{l}0.331 \\
(0.194)\end{array}$ & $\begin{array}{c}0.518 \\
(0.385)\end{array}$ & $0.187 * * *$ \\
\hline & Lower-level Mgmt./Board & $\begin{array}{l}1.560 \\
(0.387)\end{array}$ & $\begin{array}{l}1.560 \\
(0.486)\end{array}$ & 0.000 \\
\hline & $\log ($ Board Size $)$ & $\begin{array}{l}2.550 \\
(0.501)\end{array}$ & $\begin{array}{l}2.290 \\
(0.371)\end{array}$ & $-0.260 * * *$ \\
\hline & Chairman is CEO & $\begin{array}{c}0.781 \\
(0.413)\end{array}$ & $\begin{array}{c}0.602 \\
(0.490)\end{array}$ & $-0.180 * * *$ \\
\hline
\end{tabular}




\section{Table 4 Descriptive statistics of banks}

The table provides descriptive statistics of quarterly data of bank-specific variables over the time period 2006:Q1 2010:Q3. The variables are described in Table 1. For each variable, we report its mean and standard deviation in parentheses below. SIFIs (systemically important financial institutions) are defined as banks with assets larger $\$ 50 \mathrm{bn}$. in at least one quarter in our time period. The statistical significance of differences is determined via a t-test for unpaired data with unequal variance and indicated by $*=10 \%$ level, $* *=5 \%$ level and $* * *=1 \%$ level.

\begin{tabular}{|c|c|c|c|c|}
\hline & $\begin{array}{c}\text { Total } \\
(\mathrm{n}=6,152)\end{array}$ & $\begin{array}{l}\text { No Failure } \\
(\mathrm{n}=4,617)\end{array}$ & $\begin{array}{c}\text { Failure } \\
(\mathrm{n}=1,288)\end{array}$ & Difference \\
\hline $\begin{array}{l}\text { Number of Banks } \\
\text { Accounting Variables }\end{array}$ & 341 & 256 & 85 & \\
\hline Total Assets (\$-Thd.) & $\begin{array}{c}8,867,470 \\
(76,700,000)\end{array}$ & $\begin{array}{l}11,000,000 \\
(86,100,000)\end{array}$ & $\begin{array}{c}990,464 \\
(1,726,073)\end{array}$ & $10,009,536^{* * *}$ \\
\hline Total Assets (\$-Thd.) excluding SIFIs & $\begin{array}{l}1,729,611 \\
(3,263,528)\end{array}$ & $\begin{array}{l}1,935,810 \\
(3,549,197)\end{array}$ & $\begin{array}{c}990,464 \\
(1,726,073)\end{array}$ & $945,346^{* * *}$ \\
\hline Capital Ratio & $\begin{array}{c}9.563 \% \\
(0.032)\end{array}$ & $\begin{array}{c}9.777 \% \\
(0.026)\end{array}$ & $\begin{array}{l}8.757 \% \\
(0.047)\end{array}$ & $-1.020 \% * * *$ \\
\hline Total Loans excl. C\&D/Assets & $\begin{array}{c}58.977 \% \\
(0.122)\end{array}$ & $\begin{array}{c}61.057 \% \\
(0.107)\end{array}$ & $\begin{array}{c}51.119 \% \\
(0.143)\end{array}$ & $-9.938 \% * * *$ \\
\hline $\begin{array}{l}\text { Construction \& Development (C\&D) } \\
\text { Loans/Assets }\end{array}$ & $\begin{array}{c}11.364 \% \\
(0.115)\end{array}$ & $\begin{array}{c}7.420 \% \\
(0.063)\end{array}$ & $\begin{array}{c}26.259 \% \\
(0.142)\end{array}$ & $18.839 \% * * *$ \\
\hline Loan Concentration & $\begin{array}{c}0.653 \\
(0.155)\end{array}$ & $\begin{array}{c}0.626 \\
(0.152)\end{array}$ & $\begin{array}{c}0.753 \\
(0.122)\end{array}$ & $12.645 \% * * *$ \\
\hline ST Deposits/Assets & $\begin{array}{c}12.092 \% \\
(0.090)\end{array}$ & $\begin{array}{c}12.511 \% \\
(0.094)\end{array}$ & $\begin{array}{c}10.515 \% \\
(0.070)\end{array}$ & $-1.996 \% * * *$ \\
\hline Brokered Deposits/Assets & $\begin{array}{c}4.407 \% \\
(0.079)\end{array}$ & $\begin{array}{c}3.108 \% \\
(0.050)\end{array}$ & $\begin{array}{c}9.310 \% \\
(0.133)\end{array}$ & $6.201 \% * * *$ \\
\hline Return on Assets & $\begin{array}{c}0.187 \% \\
(0.014)\end{array}$ & $\begin{array}{c}0.427 \% \\
(0.008)\end{array}$ & $\begin{array}{c}-0.718 \% \\
(0.025)\end{array}$ & $-1.145 \% * * *$ \\
\hline Non-perform. Loans/Assets & $\begin{array}{l}1.709 \% \\
(0.029)\end{array}$ & $\begin{array}{l}1.180 \% \\
(0.016)\end{array}$ & $\begin{array}{l}3.707 \% \\
(0.051)\end{array}$ & $2.527 \% * * *$ \\
\hline Loan Growth & $\begin{array}{l}1.585 \% \\
(0.065)\end{array}$ & $\begin{array}{l}1.511 \% \\
(0.059)\end{array}$ & $\begin{array}{c}1.865 \% \\
(0.081)\end{array}$ & $0.354 \% * * *$ \\
\hline MBS/Assets & $\begin{array}{l}7.718 \% \\
(0.077)\end{array}$ & $\begin{array}{l}8.457 \% \\
(0.081)\end{array}$ & $\begin{array}{l}4.939 \% \\
(0.052)\end{array}$ & $-3.518 \% * * *$ \\
\hline Unused Commitm./Assets & $\begin{array}{c}24.056 \% \\
(0.281)\end{array}$ & $\begin{array}{l}24.141 \% \\
(0.197)\end{array}$ & $\begin{array}{c}23.736 \% \\
(0.482)\end{array}$ & $-0.404 \%$ \\
\hline \multicolumn{5}{|l|}{ Market Competition Variables } \\
\hline Local Market Power & $\begin{array}{c}13.612 \% \\
(0.069)\end{array}$ & $\begin{array}{c}13.823 \% \\
(0.066)\end{array}$ & $\begin{array}{c}12.804 \% \\
(0.080)\end{array}$ & $-1.019 \% * * *$ \\
\hline Comps.' Subprime Exposure & $\begin{array}{l}4.571 \% \\
(0.035)\end{array}$ & $\begin{array}{c}4.751 \% \\
(0.036)\end{array}$ & $\begin{array}{l}3.889 \% \\
(0.031)\end{array}$ & $-0.862 \% * * *$ \\
\hline \multicolumn{5}{|l|}{ State-Level Economic Variables } \\
\hline House Price Inflation & $\begin{array}{c}-0.665 \% \\
(0.021)\end{array}$ & $\begin{array}{c}-0.502 \% \\
(0.018)\end{array}$ & $\begin{array}{c}-1.282 \% \\
(0.027)\end{array}$ & $-0.780 \% * * *$ \\
\hline$\%$-Change in GDP & $\begin{array}{c}0.836 \% \\
(0.012)\end{array}$ & $\begin{array}{c}0.837 \% \\
(0.011)\end{array}$ & $\begin{array}{c}0.830 \% \\
(0.012)\end{array}$ & $-0.007 \%$ \\
\hline \multicolumn{5}{|l|}{ Primary Federal Regulator } \\
\hline OCC & $\begin{array}{c}27.259 \% \\
(0.445)\end{array}$ & $\begin{array}{c}28.516 \% \\
(0.452)\end{array}$ & $\begin{array}{c}22.516 \% \\
(0.418)\end{array}$ & \\
\hline FED & $\begin{array}{c}19.490 \% \\
(0.396)\end{array}$ & $\begin{array}{c}19.922 \% \\
(0.399)\end{array}$ & $\begin{array}{c}17.857 \% \\
(0.383)\end{array}$ & \\
\hline
\end{tabular}




\section{Table $5 \quad$ Regression results}

This table reports in Model I results from logit regressions of bankruptcy indicators on predictor variables. Model II shows results of a probit regression model with sample selection following Heckman (1979) and includes standard errors derived via the Huber (1967) - White (1980) sandwich estimator, clustered at the bank level. The selection equation is Corporate Governance Data available $=\alpha+\beta_{1} * \ln ($ Assets $)+\beta_{2} *(\ln (\text { Assets }))^{2}+\beta_{3} *$ Real Estate Loans + $\beta_{5}{ }^{*}$ Cumulative Operating Income from 2004:Q1-2006:Q4 $+\beta_{5}{ }^{*}$ Agricultural Loans $+\beta_{6} *$ Commercial Loans + $\beta_{7}{ }^{*}$ Individual Loans $+\beta_{8} *$ Public Bank $+\beta_{9} *$ Multibank Holding Company $+\beta_{10} * O C C+\beta_{11} * F E D$, where the operating income and the loan variables are employed relative to a bank's total assets and total loans, respectively. We also report the results for the Wald test of no sample selection bias, i.e. the p-value for the null of no correlation between the errors of the selection equation and the regression model. All variables are defined in Table 1. Panel B uses the same specifications as Panel A but replaces the variables "Share Ownership / Total Shares" and "Option Holdings / Total Assets" for each of the four governance groups by the logarithmized US-\$ value of share ownership and option value. In both Panels, the "Variable Compensation Variables" are lagged by one year to account for the

year when performance is measured. Robust standard errors are employed in model I and standard errors are clustered at the bank level in all models. The statistical significance of results is indicated by $*=10 \%$ level, $* *=5 \%$ level and $* * *=1 \%$ level. 


\begin{tabular}{|c|c|c|c|c|c|c|c|}
\hline \multirow{4}{*}{\multicolumn{2}{|c|}{$\begin{array}{l}\text { Panel A: Regression results including } \\
\text { Percentage Ownership }\end{array}$}} & \multirow{2}{*}{\multicolumn{3}{|c|}{ I }} & \multicolumn{3}{|c|}{ II } \\
\hline & & & & & \multicolumn{3}{|c|}{ Heckman Selection Model } \\
\hline & & \multicolumn{2}{|c|}{ Failure in } & \multirow{2}{*}{ 2006:Q4 } & \multicolumn{2}{|c|}{ Failure in } & \multirow{2}{*}{ 2006:Q4 } \\
\hline & & 1 Year & 2 Years & & 1 Year & 2 Years & \\
\hline \multicolumn{8}{|c|}{ Corporate Governance Variables } \\
\hline & Ownership Variables & & & & & & \\
\hline \multirow{4}{*}{$\begin{array}{l}\text { Share } \\
\text { Ownership / } \\
\text { Total Shares }\end{array}$} & Outside Directors & $-2.766^{* *}$ & 0.355 & 4.121 & $-1.330^{* * *}$ & 0.046 & 1.194 \\
\hline & CEO & 1.648 & -2.880 & -19.714 & 0.246 & -1.388 & -8.585 \\
\hline & Other higher-level Mgmt. & $0.791 *$ & $7.068 * * *$ & $30.782 *$ & $0.144 * *$ & $3.558 * * *$ & $12.757 * * *$ \\
\hline & Lower-level Mgmt. & $2.790 * * *$ & $2.105^{* *}$ & $9.903^{* *}$ & $0.884 * *$ & $0.872 * *$ & $2.956^{* *}$ \\
\hline \multirow{9}{*}{$\begin{array}{l}\text { Option } \\
\text { Holdings / Total } \\
\text { Assets (\$-Thd.) }\end{array}$} & Outside Directors & 5.446 & 9.409 & 6.256 & 0.791 & 4.971 & 1.640 \\
\hline & $\mathrm{CEO}$ & -0.159 & -0.106 & 0.098 & -0.065 & -0.048 & 0.005 \\
\hline & Other higher-level Mgmt. & -0.573 & -0.599 & -3.341 & -0.175 & -0.457 & -1.092 \\
\hline & Lower-level Mgmt. & 0.993 & 0.094 & -2.204 & $0.533 * *$ & -0.069 & -0.528 \\
\hline & Other Ownership Variables & & & & & & \\
\hline & TARP & $-1.562 * *$ & & & $-0.733 * * *$ & & \\
\hline & Public Bank & 0.573 & $1.101 * *$ & $3.137 * * *$ & $1.303^{* * *}$ & 0.054 & -0.587 \\
\hline & Multibank Holding Company & 0.627 & 0.495 & 2.711 & 0.093 & 0.209 & 0.410 \\
\hline & Variable Compensation Variables & & & & & & \\
\hline \multirow{4}{*}{$\begin{array}{l}\text { Stock \& Option } \\
\text { Awards / Total } \\
\text { Compensation }\end{array}$} & Outside Directors & $3.026^{*}$ & 1.632 & -3.944 & $1.423^{* *}$ & 0.877 & -1.867 \\
\hline & CEO & -1.074 & 0.619 & -2.930 & -0.069 & 0.336 & -0.784 \\
\hline & Other higher-level Mgmt. & 0.398 & -1.201 & 2.729 & -0.221 & -0.434 & 0.580 \\
\hline & Lower-level Mgmt. & -0.296 & 0.825 & -1.518 & -0.425 & 0.254 & 0.571 \\
\hline \multirow{3}{*}{$\begin{array}{l}\text { Bonus / Total } \\
\text { Compensation }\end{array}$} & $\mathrm{CEO}$ & 0.589 & -0.384 & 3.725 & -0.039 & -0.121 & 2.234 \\
\hline & Other higher-level Mgmt. & -1.990 & -2.931 & $9.422 *$ & -1.273 & -1.602 & $4.568 * *$ \\
\hline & Lower-level Mgmt. & 0.806 & 2.959 & $16.741^{* * *}$ & 1.261 & 1.481 & $6.457 * * *$ \\
\hline & Management Variables & & & & & & \\
\hline & Outside Directors/Board & -0.310 & -1.125 & 3.257 & 0.078 & -0.631 & 0.961 \\
\hline & Higher-level Mgmt./Board & -0.371 & 0.039 & $12.207^{* * *}$ & -0.074 & 0.085 & $4.278 * * *$ \\
\hline & Lower-level Mgmt./Board & 1.168 & 0.249 & -1.968 & 0.383 & 0.093 & -0.173 \\
\hline & $\log ($ Board Size $)$ & -0.733 & -0.632 & 1.311 & $-0.510 * * *$ & -0.185 & 0.525 \\
\hline & Chairman is CEO & $-0.715^{*}$ & $-0.537 * *$ & $-0.981 *$ & $-0.418 * *$ & $-0.302^{*}$ & $-0.600 *$ \\
\hline \multicolumn{8}{|c|}{ Accounting Variables } \\
\hline & $\log$ (Assets) & $-0.472 *$ & -0.181 & $-0.900^{*}$ & -0.043 & -0.160 & $-0.643^{* * *}$ \\
\hline & Capital Ratio & $-33.423 * *$ & 2.686 & -9.252 & $-12.971 * * *$ & 1.417 & -4.517 \\
\hline & Total Loans excl. C\&D/Assets & -2.909 & -0.352 & -1.184 & $-1.617 *$ & 0.206 & -0.726 \\
\hline & C\&D Loans/Assets & 1.485 & $8.761 * * *$ & $36.933 * * *$ & 0.523 & $4.416^{* * *}$ & $13.390 * * *$ \\
\hline & Loan Concentration & 1.099 & -0.689 & 7.707 & -0.017 & -0.408 & $2.742 * *$ \\
\hline & ST Deposits/Assets & $-9.613 * * *$ & -4.223 & 3.020 & $-5.247 * * *$ & $-1.931^{*}$ & 1.935 \\
\hline & Brokered Deposits/Assets & $4.853 * *$ & 1.535 & -4.377 & $2.438 * * *$ & 0.322 & -0.161 \\
\hline & Return on Assets & $-28.238 * * *$ & $-20.745^{* *}$ & $-187.739 * *$ & $-9.825^{* *}$ & $-11.027 * * *$ & $-70.521 * *$ \\
\hline & Non-perform. Loans/Assets & $18.506 * * *$ & 9.196 & $268.494 * *$ & $6.493^{* *}$ & 4.575 & $124.147 * * *$ \\
\hline & Loan Growth & $-13.811^{* * *}$ & 0.990 & 10.182 & $-5.313^{* * *}$ & 0.486 & $3.291 * * *$ \\
\hline & MBS/Assets & -0.170 & -1.584 & -11.488 & -0.669 & -0.834 & -0.787 \\
\hline & Unused Commitm./Assets & $-4.091 *$ & $-4.705^{* *}$ & $9.104^{* *}$ & $-2.317 * * *$ & -1.826 & $2.564 * *$ \\
\hline Market Competiti & on Variables & & & & & & \\
\hline & Local Market Power & $-11.869 *$ & -7.003 & -31.170 & $-4.170 *$ & -4.111 & $-9.723 * *$ \\
\hline & (Local Market Power) $^{2}$ & 12.602 & 10.672 & 77.079 & 3.437 & 6.989 & $25.470 * * *$ \\
\hline & Comps.' Subprime Exposure & $-18.159^{* * *}$ & -4.110 & -27.467 & $-8.015^{* * *}$ & -1.049 & -6.520 \\
\hline State-Level Econ & mic Variables & & & & & & \\
\hline & House Price Inflation & -3.839 & $-40.249 * * *$ & -34.901 & -3.271 & $-19.051 * * *$ & -8.332 \\
\hline & $\%$-Change in GDP & $-70.189^{* * *}$ & 6.778 & 2.661 & $-33.005 * * *$ & 4.121 & 45.977 \\
\hline Primary Federal & Regulator Variables & & & & & & \\
\hline & OCC & $1.195^{* *}$ & $0.927 *$ & 2.001 & $0.614 * * *$ & $0.372 *$ & 0.380 \\
\hline & FED & 0.280 & 0.057 & 1.116 & 0.123 & -0.049 & 0.395 \\
\hline & Constant & $8.515^{*}$ & -0.328 & -9.122 & 1.333 & 0.824 & 1.457 \\
\hline & Observations & 3,290 & 3,097 & 192 & 78,586 & 78,319 & 4,198 \\
\hline & Censored Observations & & & & 75,296 & 75,222 & 4,006 \\
\hline & Uncensored Observations & & & & 3,290 & 3,097 & 192 \\
\hline & Number of Failures & 47 & 48 & 48 & 47 & 48 & 48 \\
\hline & & McFadde & adj. Pseud & -squared: & Wald te & $\mathrm{f}$ indep. eqn & $($ rho $=0)$ : \\
\hline & & $41.5 \%$ & $25.8 \%$ & $52.3 \%$ & $18.72 \%$ & $67.61 \%$ & $67.09 \%$ \\
\hline
\end{tabular}




\begin{tabular}{|c|c|c|c|c|c|c|c|}
\hline \multirow{4}{*}{\multicolumn{2}{|c|}{$\begin{array}{l}\text { Panel B: Regression results including \$- } \\
\text { value of Ownership }\end{array}$}} & \multirow{2}{*}{\multicolumn{3}{|c|}{ I }} & \multicolumn{3}{|c|}{ II } \\
\hline & & & & & \multicolumn{3}{|c|}{ Heckman Selection Model } \\
\hline & & \multicolumn{2}{|c|}{ Failure in } & \multirow{2}{*}{ 2006:Q4 } & \multicolumn{2}{|c|}{ Failure in } & \multirow{2}{*}{ 2006:Q4 } \\
\hline & & 1 Year & 2 Years & & 1 Year & 2 Years & \\
\hline \multicolumn{8}{|c|}{ Corporate Governance Variables } \\
\hline & Ownership Variables & & & & & & \\
\hline \multirow{4}{*}{$\begin{array}{l}\log (\$-\text { Share } \\
\text { Ownership) }\end{array}$} & Outside Directors & 0.132 & 0.148 & 1.414 & 0.020 & 0.062 & 0.548 \\
\hline & $\mathrm{CEO}$ & -0.050 & -0.005 & 0.331 & -0.013 & 0.002 & $0.141 * *$ \\
\hline & Other higher-level Mgmt. & $0.036^{*}$ & $0.097 * *$ & $0.719 * * *$ & $0.027 *$ & $0.037 * *$ & $0.281 * * *$ \\
\hline & Lower-level Mgmt. & $0.146^{* *}$ & $0.066^{*}$ & $0.128 * *$ & $0.052 * *$ & $0.023 * *$ & $0.015 * * *$ \\
\hline \multirow{9}{*}{$\begin{array}{l}\log (\$-O p t i o n \\
\text { Holdings })\end{array}$} & Outside Directors & $0.284 * * *$ & $0.263 * *$ & $0.303 *$ & $0.090 *$ & $0.110 * * *$ & 0.127 \\
\hline & $\mathrm{CEO}$ & 0.065 & $0.105 *$ & -0.476 & 0.031 & $0.051^{* *}$ & -0.223 \\
\hline & Other higher-level Mgmt. & -0.035 & -0.068 & 0.376 & -0.009 & -0.043 & $0.183^{*}$ \\
\hline & Lower-level Mgmt. & 0.032 & 0.019 & 0.174 & 0.017 & 0.015 & $0.096^{*}$ \\
\hline & Other Ownership Variables & & & & & & \\
\hline & TARP & -1.096 & & & $-0.630 * * *$ & & \\
\hline & Public Bank & 0.562 & 0.569 & $4.081 * * *$ & $1.316^{* * *}$ & $0.793^{*}$ & $3.072 * * *$ \\
\hline & Multibank Holding Company & $1.312 * * *$ & $1.153 * *$ & $5.397 * * *$ & $0.504 * *$ & $0.485 * *$ & $2.293^{* *}$ \\
\hline & Variable Compensation Variables & & & & & & \\
\hline \multirow{4}{*}{$\begin{array}{c}\text { Stock \& } \\
\text { Option } \\
\text { Awards / } \\
\text { Total } \\
\text { Compensation } \\
\end{array}$} & Outside Directors & $2.686^{*}$ & 1.513 & -4.688 & $1.405^{* *}$ & $0.843 *$ & -0.714 \\
\hline & CEO & -1.401 & 0.779 & -5.502 & -0.238 & 0.287 & $-3.968 * *$ \\
\hline & Other higher-level Mgmt. & 0.481 & -0.994 & 4.531 & -0.093 & -0.484 & 3.792 \\
\hline & Lower-level Mgmt. & -0.949 & 0.286 & 8.929 & -0.693 & -0.080 & $3.389^{*}$ \\
\hline \multirow{19}{*}{$\begin{array}{l}\text { Bonus / Total } \\
\text { Compensation }\end{array}$} & $\mathrm{CEO}$ & -1.653 & -1.073 & 1.967 & -0.231 & -0.325 & 1.915 \\
\hline & Other higher-level Mgmt. & -4.147 & -5.301 & -1.656 & -2.417 & -2.200 & -0.267 \\
\hline & Lower-level Mgmt. & 0.110 & 1.946 & $23.551 * * *$ & 0.410 & 0.637 & $9.838^{* *}$ \\
\hline & Management Variables & & & & & & \\
\hline & Outside Directors/Board & -1.004 & -1.769 & -4.191 & -0.225 & -0.863 & -0.553 \\
\hline & Higher-level Mgmt./Board & 0.735 & 1.322 & $18.817 * * *$ & 0.381 & 0.505 & $7.475^{* * *}$ \\
\hline & Lower-level Mgmt./Board & 0.302 & -0.758 & -0.084 & 0.046 & -0.263 & -0.410 \\
\hline & $\log$ (Board Size $)$ & $-1.048^{*}$ & -0.878 & 0.333 & $-0.544 * *$ & -0.407 & -0.140 \\
\hline & Chairman is CEO & $-0.919 * *$ & $-0.851 * *$ & $-3.187 * *$ & $-0.432 * *$ & $-0.374 * *$ & $-1.159 * *$ \\
\hline & Accounting Variables & Yes & Yes & Yes & Yes & Yes & Yes \\
\hline & Market Competition Variables & Yes & Yes & Yes & Yes & Yes & Yes \\
\hline & State-Level Economic Variables & Yes & Yes & Yes & Yes & Yes & Yes \\
\hline & Primary Federal Regulator Variables & Yes & Yes & Yes & Yes & Yes & Yes \\
\hline & Observations & 3,290 & 3,097 & 192 & 78,586 & 78,319 & 4,198 \\
\hline & Censored Observations & & & & 75,296 & 75,222 & 4,006 \\
\hline & Uncensored Observations & & & & 3,290 & 3,097 & 192 \\
\hline & Number of Failures & 47 & 48 & 48 & 47 & 48 & 48 \\
\hline & & \multicolumn{3}{|c|}{ McFadden's adj. Pseudo R-squared: } & \multicolumn{3}{|c|}{ Wald test of indep. eqns. $($ rho $=0)$ : } \\
\hline & & $40.5 \%$ & $26.8 \%$ & $52.5 \%$ & $45.06 \%$ & $33.73 \%$ & $56.38 \%$ \\
\hline
\end{tabular}




\section{Table 6}

\section{Main regression results by bank characteristics and size}

This table reports results from logit regressions of bankruptcy indicators on predictor variables. In all regressions, the table includes all control variables from Table 5 except the compensation variables. Bank characteristics are proxied by three variables. Regression I reports the base model. In regression set II the indicator variable "Chairman is CEO" is employed as proxy variable. It is one when the CEO of a bank is also the Chairman of the Board of this bank. Regression set III uses an indicator variable which is one when the bank's total assets are smaller than the $25^{\text {th }}$ percentile of the total assets of all banks with available corporate governance data. Regression set IV employs an indicator variable which is one when the bank has no publicly traded securities. Robust standard errors are employed and clustered at the bank level. The statistical significance of results is indicated by $*=10 \%$ level, $* *=5 \%$ level and $* * *=1 \%$.

\begin{tabular}{|c|c|c|c|c|c|c|c|c|c|c|c|c|}
\hline & \multicolumn{3}{|c|}{$\mathrm{I}$} & \multicolumn{3}{|c|}{ II } & \multicolumn{3}{|c|}{ III } & \multicolumn{3}{|c|}{ IV } \\
\hline & \multicolumn{3}{|c|}{ Base Model } & \multicolumn{3}{|c|}{$\begin{array}{c}\text { Banks with } \\
\text { Chairman = CEO }\end{array}$} & \multicolumn{3}{|c|}{$\begin{array}{c}\text { Banks with } \\
\text { Assets }<25 \text { th percentile }\end{array}$} & \multicolumn{3}{|c|}{ Non-Publicly traded Banks } \\
\hline & \multicolumn{2}{|c|}{ Failure in } & \multirow{2}{*}{ 2006:Q4 } & \multicolumn{2}{|c|}{ Failure in } & \multirow{2}{*}{ 2006:Q4 } & Failu & e in & & \multicolumn{2}{|c|}{ Failure in } & \multirow{2}{*}{ 2006:Q4 } \\
\hline & 1 Year & 2 Years & & 1 Year & 2 Years & & 1 Year & 2 Years & 2006:Q4 & 1 Year & 2 Years & \\
\hline $\begin{array}{l}\text { Corporate Governance Variables } \\
\text { Share Ownership / Total Shares } \\
\text { CEO }\end{array}$ & 1.359 & -3.265 & -10.221 & & & & & & & & & \\
\hline Indicator $=0$ & & & & 6.966 & -4.537 & 239.501 & 9.676 & 0.667 & 5.827 & 14.905 & 2.589 & -1.051 \\
\hline Indicator $=1$ & & & & 1.260 & -2.049 & -0.371 & -0.137 & $-5.764^{*}$ & $-42.471 *$ & -5.237 & $-9.029 *$ & $-26.948^{*}$ \\
\hline Higher-level Mgmt. & $1.185^{*}$ & $7.389 * * *$ & $28.003 *$ & & & & & & & & & \\
\hline Indicator $=0$ & & & & $8.072 *$ & $4.517^{* *}$ & $28.743 * *$ & $2.755^{*}$ & $6.219 * *$ & $19.151 * * *$ & $0.599 *$ & $4.825^{* *}$ & $8.933 * * *$ \\
\hline Indicator $=1$ & & & & -1.396 & 7.342 & 21.951 & -0.947 & 17.873 & 195.699 & -6.270 & 19.776 & 71.274 \\
\hline Lower-level Mgmt. & $2.609 * * *$ & $2.029 * *$ & $3.653^{* *}$ & & & & & & & & & \\
\hline Indicator $=0$ & & & & $3.795 * * *$ & $3.223^{* *}$ & $10.148^{* *}$ & $4.458^{* * *}$ & $1.882 * *$ & $4.831 *$ & $3.744 * * *$ & $1.754 * * *$ & $7.507 * * *$ \\
\hline Indicator $=1$ & & & & 1.142 & 1.064 & 0.737 & 1.111 & 1.777 & 3.547 & 0.531 & 1.275 & -3.748 \\
\hline Outside Directors & $-2.860^{* *}$ & 0.290 & 1.924 & & & & & & & & & \\
\hline Indicator $=0$ & & & & $-2.400 *$ & 2.038 & 8.336 & $-5.772 * * *$ & $-1.357^{*}$ & $-5.750^{*}$ & $-4.170^{* *}$ & $-0.217 * *$ & 3.773 \\
\hline Indicator $=1$ & & & & -2.845 & -0.882 & -9.960 & -0.687 & 1.029 & 8.512 & -1.681 & 0.311 & 1.763 \\
\hline Chairman = CEO & $-0.615^{*}$ & $-0.509^{* *}$ & $-0.520^{*}$ & -0.250 & 0.177 & 4.081 & & & & & & \\
\hline Bank Assets $<25$ th percentile & & & & & & & -1.245 & -0.521 & $-3.368^{* *}$ & & & \\
\hline Non-Publicly traded Banks & & & & & & & & & & -0.596 & -1.069 & -3.222 \\
\hline All Other Ownership Variables & Yes & Yes & Yes & Yes & Yes & Yes & Yes & Yes & Yes & Yes & Yes & Yes \\
\hline Management Variables & Yes & Yes & Yes & Yes & Yes & Yes & Yes & Yes & Yes & Yes & Yes & Yes \\
\hline Accounting Variables & Yes & Yes & Yes & Yes & Yes & Yes & Yes & Yes & Yes & Yes & Yes & Yes \\
\hline Market Competition Variables & Yes & Yes & Yes & Yes & Yes & Yes & Yes & Yes & Yes & Yes & Yes & Yes \\
\hline State-Level Economic Variables & Yes & Yes & Yes & Yes & Yes & Yes & Yes & Yes & Yes & Yes & Yes & Yes \\
\hline $\begin{array}{l}\text { Primary Federal Regulator } \\
\text { Variables }\end{array}$ & Yes & Yes & Yes & Yes & Yes & Yes & Yes & Yes & Yes & Yes & Yes & Yes \\
\hline Observations & 3,290 & 3,097 & 192 & 3,290 & 3,097 & 192 & 3,290 & 3,097 & 192 & 3,290 & 3,097 & 192 \\
\hline McFadden's adj. Pseudo R-squ. & $43.0 \%$ & $27.2 \%$ & $51.7 \%$ & $42.2 \%$ & $26.6 \%$ & $53.3 \%$ & $42.6 \%$ & $26.1 \%$ & $51.4 \%$ & $42.6 \%$ & $26.5 \%$ & $50.6 \%$ \\
\hline
\end{tabular}




\section{Table $7 \quad$ Regression results for accounting measures of bank risk}

This table reports results for measures of bank risk using data from 2004:Q1 to 2010:Q3. The measures are the capital ratio, non-performing loans to total assets, the return on assets (RoA), all defined as in Table 1, as well as the non-interest income to total assets as reported on the balance sheet and the natural logarithm of the Z-score. The natural logarithm of the Z-score is defined as the sum of the capital ratio and the RoA divided by the standard deviation of the RoA over the previous 8 quarters. Panel A shows descriptive results of quarterly data where the difference between failure and non-failure banks is tested via a t-test for unpaired data with unequal variance and indicated by $*=10 \%$ level, $* *=5 \%$ level and $* * *=1 \%$ level. Panel B reports cross-sectional regression results of risk measures on control variables measured in 2006:Q4. The control variables in all regressions are the Ownership, Compensation, Management, Accounting, Market-Competition, State-level Economic and Primary Federal Regulator Variables as used in Table 5 excluding some variables to account for potential endogeneity. The latter are in Panel B1 the capital ratio, in Panel B2 non-performing loans/assets, in Panel B3 the capital ratio and the return on assets, and in Panel B4 the return on assets. All results for the full set of control variables from Table 5 as well as for the specifications just described are shown in the Online Appendix. For the derivation of the respective dependent variables at the bank-level we use the period 2007:Q1 to 2010:Q3 and in Panels B1 and B3 quarterly differences of the Capital Ratio and the natural logarithm of the Z-score, respectively, where all other panels use quarterly data of non-performing loans to total assets, the return on assets and non-interest income to total assets, respectively. For the kurtosis we use the excess kurtosis. The "extreme bad value" in Panel B is the minimum of the respective variable at the bank-level over the period 2007:Q1 to 2010:Q3, except for non-performing loans where it is the maximum. Standard errors are robust to heteroscedasticity and statistical significances indicated by $*=10 \%$ level, $* *=5 \%$ level and $* * *=1 \%$.

\begin{tabular}{|c|c|c|c|}
\hline Panel A: Descriptive Statistics & No Failure & Failure & Difference \\
\hline \multicolumn{4}{|l|}{ Panel A1: Capital Ratio } \\
\hline 2004 & $9.295 \%$ & $11.147 \%$ & $1.853 \% * * *$ \\
\hline 2005 & $9.434 \%$ & $10.462 \%$ & $1.028 \% * * *$ \\
\hline 2006 & $9.651 \%$ & $10.522 \%$ & $0.871 \% * * *$ \\
\hline 2007 & $9.915 \%$ & $10.585 \%$ & $0.670 \% * * *$ \\
\hline 2008 & $9.761 \%$ & $8.818 \%$ & $-0.943 \% * * *$ \\
\hline 2009 & $9.669 \%$ & $4.475 \%$ & $-5.194 \% * * *$ \\
\hline 2010 & $9.926 \%$ & $1.921 \%$ & $-8.005 \% * * *$ \\
\hline \multicolumn{4}{|l|}{ Panel A2: Non-performing Loans } \\
\hline 2004 & $0.526 \%$ & $0.341 \%$ & $-0.185 \% * * *$ \\
\hline 2005 & $0.460 \%$ & $0.359 \%$ & $-0.101 \% * *$ \\
\hline 2006 & $0.428 \%$ & $0.414 \%$ & $-0.014 \%$ \\
\hline 2007 & $0.548 \%$ & $1.188 \%$ & $0.640 \% * * *$ \\
\hline 2008 & $1.111 \%$ & $4.822 \%$ & $3.711 \% * * *$ \\
\hline 2009 & $1.863 \%$ & $9.333 \%$ & $7.470 \% * * *$ \\
\hline 2010 & $2.206 \%$ & $11.734 \%$ & $9.529 \% * * *$ \\
\hline \multicolumn{4}{|l|}{ Panel A3: $\ln (Z$-score $)$} \\
\hline 2006 & 3.367 & 3.357 & -0.010 \\
\hline 2007 & 3.380 & 3.347 & -0.032 \\
\hline 2008 & 3.337 & 2.476 & $-0.861 * * *$ \\
\hline 2009 & 3.189 & 1.353 & $-1.837 * * *$ \\
\hline 2010 & 3.269 & -0.219 & $-3.488 * * *$ \\
\hline \multicolumn{4}{|l|}{ Panel A4: Return on Assets } \\
\hline 2004 & $0.694 \%$ & $0.478 \%$ & $-0.216 \% * * *$ \\
\hline 2005 & $0.724 \%$ & $0.638 \%$ & $-0.086 \% * *$ \\
\hline 2006 & $0.736 \%$ & $0.687 \%$ & $-0.049 \%$ \\
\hline 2007 & $0.658 \%$ & $0.452 \%$ & $-0.207 \% * * *$ \\
\hline 2008 & $0.415 \%$ & $-1.273 \%$ & $-1.689 \% * * *$ \\
\hline 2009 & $0.067 \%$ & $-3.535 \%$ & $-3.602 \% * * *$ \\
\hline 2010 & $0.203 \%$ & $-1.670 \%$ & $-1.873 \% * * *$ \\
\hline \multicolumn{4}{|l|}{ Panel A5: Non-Interest Income } \\
\hline 2004 & $0.795 \%$ & $0.549 \%$ & $-0.245 \% * * *$ \\
\hline 2005 & $0.788 \%$ & $0.442 \%$ & $-0.347 \% * * *$ \\
\hline 2006 & $0.767 \%$ & $0.365 \%$ & $-0.402 \% * * * *$ \\
\hline 2007 & $0.729 \%$ & $0.337 \%$ & $-0.392 \% * * *$ \\
\hline 2008 & $0.681 \%$ & $0.315 \%$ & $-0.366 \% * * *$ \\
\hline 2009 & $0.702 \%$ & $0.088 \%$ & $-0.614 \% * * *$ \\
\hline 2010 & $0.518 \%$ & $0.165 \%$ & $-0.353 \%$ *** \\
\hline
\end{tabular}




\begin{tabular}{|c|c|c|c|c|c|c|}
\hline & \multirow{2}{*}{\multicolumn{5}{|c|}{ Dependent Variable from 2007:Q1 to 2010:Q3 }} \\
\hline \multirow{2}{*}{\multicolumn{2}{|c|}{ Panel B: Regression Results }} & & & & & \\
\hline & & Mean & St. Dev. & Skew & Kurtosis & $\begin{array}{c}\text { Bad } \\
\text { Value }\end{array}$ \\
\hline \multicolumn{2}{|c|}{ Independent Variables 2006:Q4 } & I & II & III & IV & $\mathrm{V}$ \\
\hline \multicolumn{7}{|c|}{ Panel B1: $\Delta$ Capital Ratio } \\
\hline & Ownership Variables & & & & & \\
\hline \multirow{4}{*}{$\begin{array}{c}\text { Share } \\
\text { Ownership / } \\
\text { Total Shares }\end{array}$} & Outside Directors & -0.029 & 0.001 & $-1.174 * *$ & 0.586 & -0.007 \\
\hline & CEO & 0.012 & -0.004 & 2.436 & -3.012 & 0.013 \\
\hline & Other higher-level Mgmt. & $-0.125 * * *$ & 0.007 & $-3.379^{*}$ & $7.711^{* * *}$ & $-0.038^{*}$ \\
\hline & Lower-level Mgmt. & 0.002 & -0.001 & $-0.804 *$ & -0.265 & 0.001 \\
\hline \multirow{4}{*}{$\begin{array}{c}\text { Option } \\
\text { Holdings / Total } \\
\text { Assets (\$-Thd.) }\end{array}$} & Outside Directors & -0.038 & 0.004 & 0.290 & -1.043 & -0.020 \\
\hline & CEO & 0.004 & -0.000 & 0.137 & 0.036 & 0.001 \\
\hline & Other higher-level Mgmt. & 0.010 & -0.002 & 0.067 & -0.315 & 0.006 \\
\hline & Lower-level Mgmt. & 0.007 & 0.001 & 0.174 & $0.984^{*}$ & -0.001 \\
\hline \multicolumn{7}{|c|}{ Panel B2: Non-performing Loans / Total Assets } \\
\hline \multirow{4}{*}{$\begin{array}{c}\text { Share } \\
\text { Ownership / } \\
\text { Total Shares }\end{array}$} & Outside Directors & $0.373 * * *$ & $0.019 * * *$ & 0.057 & 0.353 & $0.056 * * *$ \\
\hline & $\mathrm{CEO}$ & 0.172 & -0.023 & $-1.705^{*}$ & 0.336 & -0.045 \\
\hline & Other higher-level Mgmt. & $0.768 * * *$ & $0.050 * *$ & -1.025 & -2.298 & $0.107 *$ \\
\hline & Lower-level Mgmt. & -0.056 & -0.002 & 0.256 & $1.559^{*}$ & 0.006 \\
\hline \multirow{4}{*}{$\begin{array}{c}\text { Option } \\
\text { Holdings / Total } \\
\text { Assets (\$-Thd.) }\end{array}$} & Outside Directors & -0.001 & -0.011 & $2.299 * * *$ & $4.389 * * *$ & -0.007 \\
\hline & $\mathrm{CEO}$ & 0.005 & -0.001 & -0.036 & -0.086 & -0.002 \\
\hline & Other higher-level Mgmt. & -0.053 & -0.003 & -0.062 & -0.284 & -0.010 \\
\hline & Lower-level Mgmt. & -0.028 & 0.000 & -0.157 & $0.621 * *$ & 0.003 \\
\hline \multicolumn{7}{|c|}{ Panel B3: $\Delta$ Ln(Z-Score) } \\
\hline \multirow{4}{*}{$\begin{array}{c}\text { Share } \\
\text { Ownership / } \\
\text { Total Shares }\end{array}$} & Outside Directors & $-1.169^{*}$ & 0.163 & -0.752 & 1.484 & -0.678 \\
\hline & $\mathrm{CEO}$ & 1.260 & $-0.455^{*}$ & 0.481 & -2.069 & 1.361 \\
\hline & Other higher-level Mgmt. & -1.920 & 0.372 & -0.882 & -3.616 & -0.715 \\
\hline & Lower-level Mgmt. & -0.033 & -0.074 & 0.624 & $-1.408^{*}$ & 0.371 \\
\hline \multirow{4}{*}{$\begin{array}{c}\text { Option } \\
\text { Holdings / Total } \\
\text { Assets (\$-Thd.) }\end{array}$} & Outside Directors & $0.180 * *$ & $-0.025 * *$ & 0.132 & $0.293 * *$ & $0.082 *$ \\
\hline & $\mathrm{CEO}$ & -0.338 & -0.042 & -0.272 & -0.528 & 0.001 \\
\hline & Other higher-level Mgmt. & -0.140 & 0.144 & 0.348 & 0.593 & -0.281 \\
\hline & Lower-level Mgmt. & -1.294 & 0.117 & -0.280 & -3.432 & -0.203 \\
\hline \multicolumn{7}{|c|}{ Panel B4: Return on Assets } \\
\hline \multirow{4}{*}{$\begin{array}{c}\text { Share } \\
\text { Ownership / } \\
\text { Total Shares }\end{array}$} & Outside Directors & -0.039 & 0.003 & -0.124 & 0.840 & -0.011 \\
\hline & $\mathrm{CEO}$ & 0.037 & -0.009 & -1.066 & 1.911 & 0.003 \\
\hline & Other higher-level Mgmt. & $-0.496^{* * *}$ & $0.036^{* *}$ & $-3.382 * *$ & $2.872^{*}$ & $-0.128 * * *$ \\
\hline & Lower-level Mgmt. & -0.015 & -0.002 & 0.161 & 0.204 & 0.002 \\
\hline \multirow{4}{*}{$\begin{array}{c}\text { Option } \\
\text { Holdings / Total } \\
\text { Assets (\$-Thd.) }\end{array}$} & Outside Directors & -0.130 & $0.017 * *$ & -1.535 & 1.443 & $-0.048 *$ \\
\hline & $\mathrm{CEO}$ & 0.006 & -0.000 & 0.088 & 0.153 & 0.001 \\
\hline & Other higher-level Mgmt. & 0.021 & -0.002 & -0.305 & 0.159 & 0.003 \\
\hline & Lower-level Mgmt. & -0.013 & 0.001 & 0.369 & $-0.604 *$ & 0.001 \\
\hline \multicolumn{7}{|c|}{ Panel B5: Non-Interest Income / Total Assets } \\
\hline \multirow{4}{*}{$\begin{array}{c}\text { Share } \\
\text { Ownership / } \\
\text { Total Shares }\end{array}$} & Outside Directors & $-0.042^{*}$ & $-0.003 *$ & 0.027 & 0.369 & 0.001 \\
\hline & $\mathrm{CEO}$ & 0.215 & 0.009 & 0.530 & -1.002 & 0.004 \\
\hline & Other higher-level Mgmt. & 0.107 & $0.009 *$ & 0.634 & 0.896 & 0.000 \\
\hline & Lower-level Mgmt. & -0.010 & -0.000 & $-0.677 * *$ & $0.093^{* *}$ & 0.000 \\
\hline \multirow{4}{*}{$\begin{array}{c}\text { Option } \\
\text { Holdings / Total } \\
\text { Assets (\$-Thd.) }\end{array}$} & Outside Directors & 0.086 & 0.010 & -0.978 & 0.879 & $-0.009^{*}$ \\
\hline & CEO & -0.002 & -0.000 & -0.049 & -0.109 & 0.000 \\
\hline & Other higher-level Mgmt. & 0.004 & 0.001 & 0.350 & 0.292 & 0.000 \\
\hline & Lower-level Mgmt. & -0.017 & $-0.002 * *$ & -0.172 & $-0.504 * *$ & 0.001 \\
\hline
\end{tabular}

